\title{
Kalevipoeg ja Dobrõnja. Rahvaluule kogumisest Alutagusel 1950. aastatel
}

\author{
Liina Saarlo
}

Teesid: Artiklis annan ülevaate eesti-vene suhete teema käsitlemisest sõjajärgses eesti folkloristikas, keskendudes Keele ja Kirjanduse Instituudi rahvaluulesektori välitöödele IdaVirumaal 1950. aastate teisel poolel. Vaatlen välitööde asjaolusid muutuvates teaduspoliitilistes oludes ja kogumismeetodite uuenemise ajajärgul.

Sõjajärgse humanitaaria prioriseeritud ning omavahel põimuvad uurimisalad - vene ja eesti rahva suhted ning rahvuseepos "Kalevipoeg" - määrasid nii toonaste välitööde sisu kui ka sihtkohad. Siiski peab välitööde tulemuste ja kogutud materjali käekäigu osas tõdema, et toonased folkloristid ei süvenenud rahvastevaheliste suhete temaatikasse kuigivõrd. Venelastelt talletatud pärimust demonstreeriti küll juhtkonnale ja avalikkusele, aga ei kasutatud uurimistöös. Hiiumuistendite ja kohapärimuse kogumine ja uurimine püsis aga edukalt päevakorral.

Märksõnad: folkloristika ajalugu, eesti-vene suhted, kangelasmuistendid, poluvertsikud poluvernikud, välitööd

Eesti kodanlikud natsionalistid püüdsid isegi eesti rahvaloomingu väljapaistvamat kuju - Kalevipoega - ära kasutada vaenu õhutamiseks Nõukogude Liidu vastu: nad seadsid Tartus üles nn. Kalevipoja samba, näoga ida poole ja mõ̃ok käes. Samuti oli 
viimastes väljaannetes teadlikult võltsitud rahvaeepose "Kalevipoeg" teksti, jättes sellest välja sõbralikud väljendused Vene valitsuse kohta. Kuid eesti rahvaluule on, vastupidi, just Kalevipojas näinud oma igatsuste kehastajat: sõpruse tihendajat suure vene rahvaga. Kalevipoja kujus on rahvas unistanud tihedama liidu ja parema ühendustee loomisest Eestimaa ja Venemaa vahel. (Viidalepp 1951)

Pärast Teise maailmasõja lõppu valitses Eesti akadeemilises elus üpriski komplitseeritud olukord. Koloniaalpoliitikale omaselt muudeti sovetiseeritavas Eestis nii teaduse vormi kui ka sisu Nõukogude süsteemile vastavaks. Kunagiste uurimisteemade ja -meetodite tõttu võisid teadlased hõlpsasti sattuda poliitiliste repressioonide ohvriks. Sisuliseks tööks saadi juhiseid Moskvas toimunud konverentsidelt, mille tulemusi levitati hoolikalt koha peal. Kuid "ülevalt" tulevad suunised muutusid pidevalt - vastavalt poliitiliste liidrite soosingule või ebasoosingule.

Üks püsivalt soositud uurimisalasid sõjajärgses humanitaarias olid rahvaste vahelised suhted, eriti vene ja eesti rahva (rõhutatult positiivsed) sidemed. See teema oli eriliselt aktuaalne piirimaadel ja üleminekuajal - Peipsi järve ümbruses, Ida-Virumaal ja Kagu-Eestis 1940.-1950. aastail. Eriti tulemuslik oli nn etnilise ajaloo uurimine arheoloogide, etnograafide ning dialektoloogide materjalikogudele tuginedes. Folkloristid korraldasid mitme aasta jooksul ekspeditsioone Setumaale, Kodaverre ja Alutagusele.

Taas aktualiseerus uurimisteemana Friedrich Reinhold Kreutzwaldi (1803-1882) elu ja looming ning rahvuseepos "Kalevipoeg", mis hiiumuistendite motiivide kaudu haakus omakorda sobivalt eesti-vene suhete teemaga (nt Ahven 2007, 162, 175).

Artiklis annan ülevaate eesti-vene suhete teema käsitlemisest eesti folkloristikas, keskendudes Keele ja Kirjanduse Instituudi rahvaluulesektori välitöödele Ida-Virumaal 1950. aastate teisel poolel. Vaatlen välitööde asjaolusid muutuvates teaduspoliitilistes oludes ja kogumismeetodite uuenemise ajajärgul.

Ülevaade tugineb lisaks kogutud folkloorimaterjalidele peamiselt kogumispäevikutele, kuna trükis ilmunud materjal - rahvaluule kogumisülevaated (Tedre 1999; Korb 2017), asjaosaliste mälestused (Tedre 1997; Viidalepp 1981), Keele ja Kirjanduse Instituudi kroonikad (Ahven 2007) jmt - ei sisalda oluliselt infot nende ekspeditsioonide kohta. Seevastu üsna kohusetundlikult ja järjepidevalt kirja pandud välitööpäevikud annavad ülevaate folkloristide eesmärkidest ja töömeetoditest. Samuti annavad päevikukirjeldused mõningase ülevaate olustikust 1950. aastate Ida-Virumaal. 


\section{Teaduspoliitiline taust}

Eesti teaduse sovetiseerimise käigus reorganiseeriti teadusasutuste struktuur Nõukogude Liidu / Nõukogude Venemaa vastavate struktuuride eeskujul. Selle käigus lahutati rahvaluule kogumine-säilitamine, õpetamine ja uurimine. Eesti Rahvaluule Arhiiv (edaspidi ERA) eraldati Eesti Rahva Muuseumist, suhteliselt iseseisvast arhiivist sai 1940. aastal Riikliku Kirjandusmuuseumi (RKM) rahvaluule osakond (RO). Uutes oludes jäi osakond teisi teadusasutusi teenindavasse rolli, selle osaks jäi üksnes rahvaluule kogumine, säilitamine ning kättesaadavaks tegemine. Eesti NSV Teaduste Akadeemia allasutusena loodi Keele ja Kirjanduse Instituut (KKI), mille rahvaluule sektori ülesandeks (KKI RS) sai suulise pärandi teaduslik uurimine. KKI Tallinna kolimisega 1952. aastal lahutati folkloristid oma uurimuste allikatest, mis jäid endiselt Tartusse RKMi. ${ }^{1}$ Folkloristika kui distsipliin kaotas iseseisvuse ja liideti kirjandusteadusega. 1947. aastal ühendati Tartu Riiklikus Ülikoolis eesti kirjanduse ja rahvaluule kateeder (TRÜ EKRK), mille kohustuseks sai (muuhulgas) eesti filoloogidele rahvaluule õpetamine. Rahvaluule ülevaateid avaldati kirjandusõpikute esimese osana, millega rahvaluule taandati eelkirjanduseks (nt "Eesti kirjanduse ajalugu", EKA 1953).

1940. aastate lõpp ja 1950. aastate algus olid Eesti haridus- ja kultuurielus väga keerulised ja sünged. Sõjajärgsed hingetõmbeaastad, mida Eestis on nimetatud järel-eesti ajaks ${ }^{2}$ lõppesid 1946. aastal, mil partei (ÜK(b)P) keskkomitee mitut kunstiala puudutavate otsuste järel algas Nõukogude Liidus Stalini surmani kestnud nõiajaht mitmesugustele "reeturitele". Eestis hakati kohe arutama üleliidulisi otsuseid ja neist tegevussuuniseid võtma, repressioonid saavutasid täisvõimsuse 1950. aasta märtsis toimunud Eesti Kommunistliku (bolševike) Partei Keskkomitee VIII pleenumi järel. Ümberhindamiste ja (enese)kriitikalaine eesmärk oli puhastada kõrgkoolid ja teadusasutused, loomeliidud jm "kodanlikust natsionalismist", "formalistidest", "kosmopoliitidest" jmt. Sellised piisavalt ebakonkreetsed ettekäänded võisid süüdistusena tabada igaüht ning

${ }^{1}$ KKI RS algusest vt Ahven 2007, 23 jj; Tedre 1997, 201 jj.

${ }^{2}$ See Madis Kõivult pärinev mõiste on hästi omaks võetud eesti kultuuriloolaste seas sõjajärgse aja periodiseerimisel (nt Kalda 2002, 572; Kreegipuu 2007, 357). Kasutusel on loomulikult ka muid määratlusi, näiteks sotsiaalse indiferentsuse aeg (Aarelaid 1998, 106). 


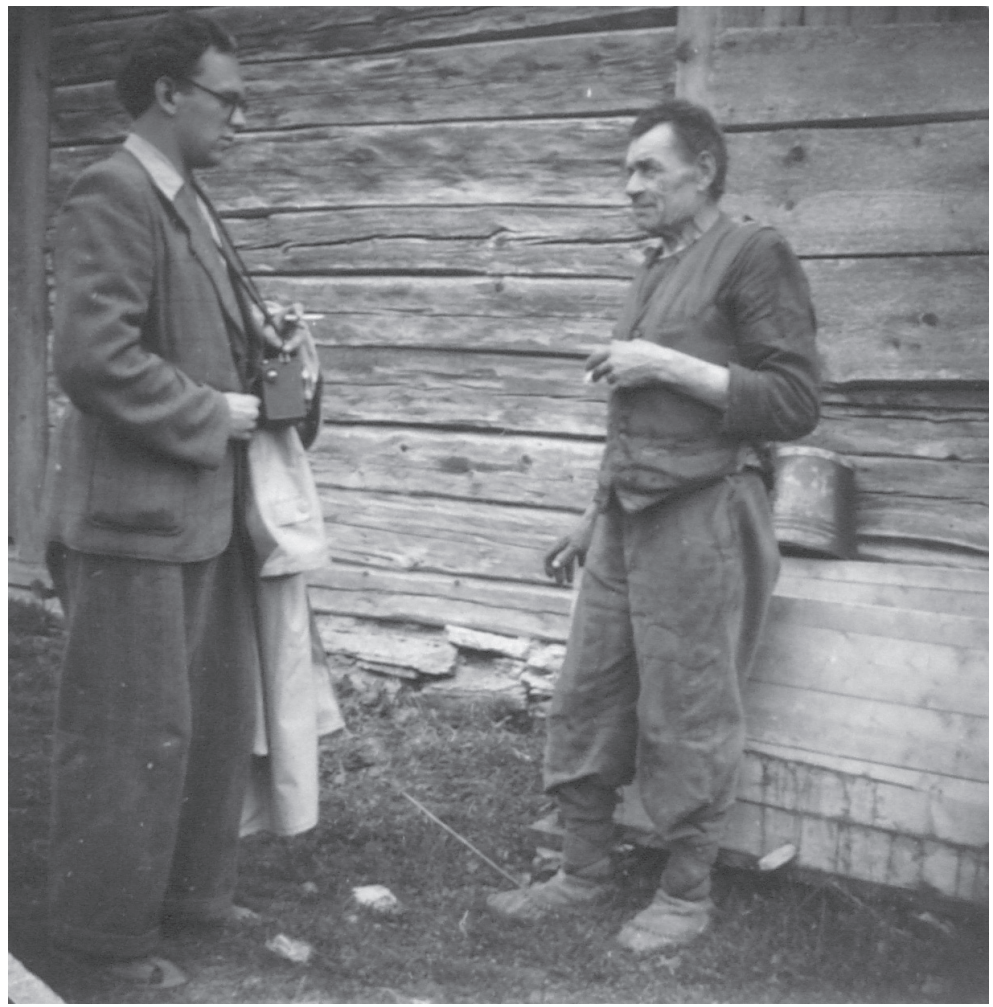

Jüri Veski "Märjamaa” kolhoosist vestlemas Ülo Tedrega.

Foto: Loreida Raudsep, 1950 (EKRK I 1, 441 (9)).

tekitasid kokkuvõttes pideva hirmuseisundi ja ebakindluse, mistõttu tagasid teadlaskonna kohandumise ja koostöö valitseva võimuga. ${ }^{3}$

Seetõttu ei olnud toona valitsenud teaduslikud uurimissuunad ja tööülesanded (toonases sõnastuses "probleemid") mitte moevooludena pakutavad valikud, vaid kohustuslikud teemad, mille

${ }^{3}$ Nendest otsustest ja tagajärgedest Eesti kultuurielule on kirjutanud näiteks Tiit Hennoste (2010 a ja b), Sirje Olesk (2003), Urve Lippus (2008). 


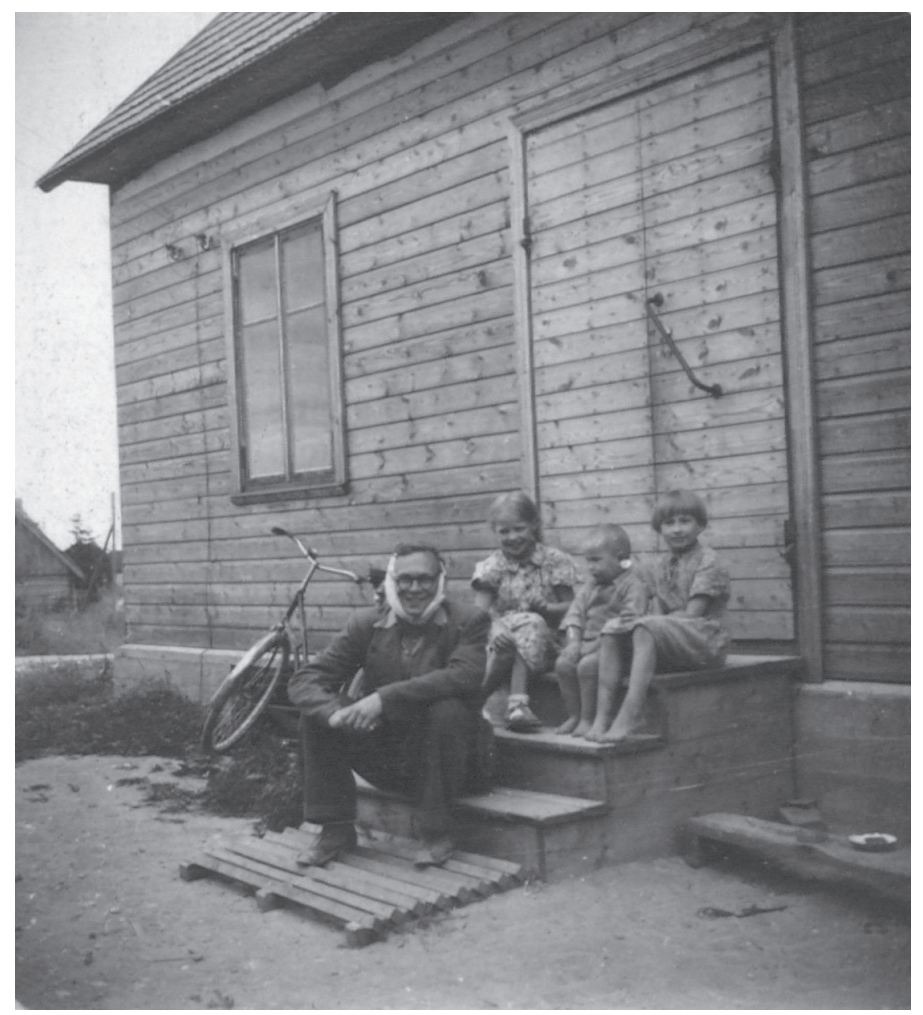

"Kuldne Kodu” kolhoosi kontor. Trepil Ülo Tedre koos Lilli Berliini jt lastega. Foto: Loreida Raudsep, 1950 (EKRK I 1, 455 (28))

ignoreerimisel pidi palgaastme või teadusliku ametikohagi kaotust lugema pääsemiseks. ${ }^{4}$

${ }^{4}$ 1945. aastal natsionalistlikus tegevuses süüdistatud ja arreteeritud üliõpilasseltsi Veljesto liikmete hulgas oli mitu ERA (endist) töötajat, neist Herbert Tampere ja Paul Ariste vabanesid aasta hiljem, Rudolf Põldmäe aga alles pärast 1955. aastat (Lippus 2008, 208). Otsestest repressioonidest pääsenud Richard Viidalepa Saksa okupatsiooni ajal kaitstud teaduslik kraad tühistati 1950. aastal, mis tõi kaasa suure kaotuse palgaastmes (Ahven 2007, 82). 


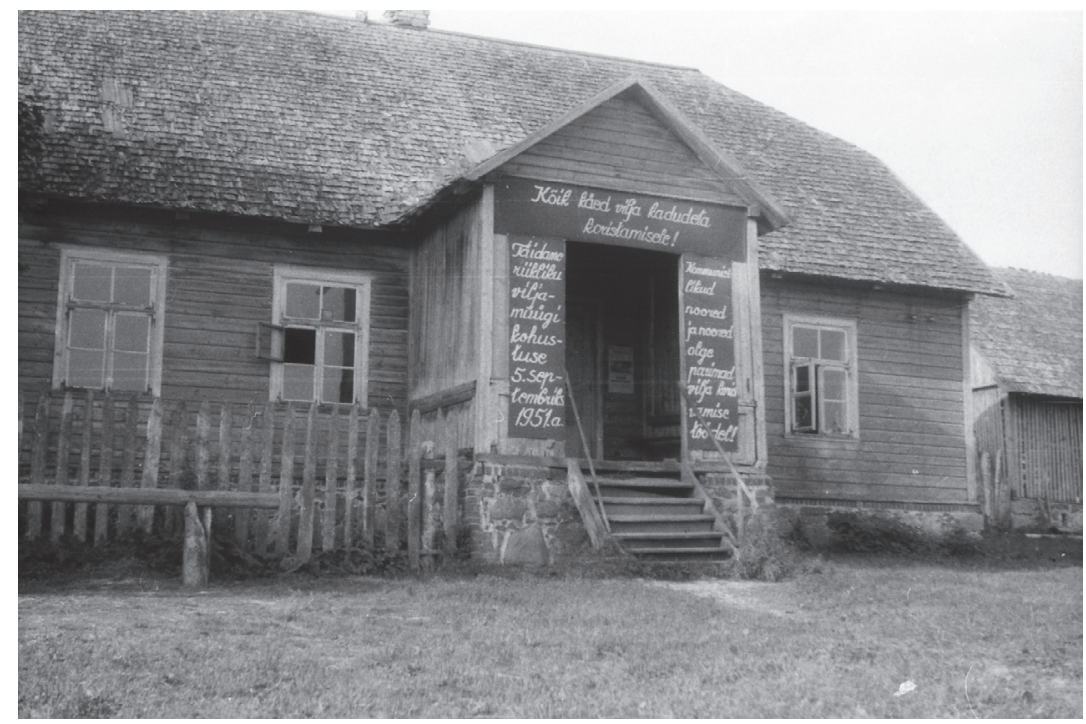

Vastseliina kolhoosi kontor. Foto: Richard Viidalepp, 1950 (KKI, Foto 111).

Samas ei tahaks päris kõrvale jätta mõtet, et folkloristid võisid uute nõuetega ka kohaneda ning pööratagi silmad uute uurimisparadigmade poole - mis pealegi ei pruukinudki olla päris enneolematud. Kuigi sõjaeelses Eestis oli folkloristide põhitähelepanu pööratud Hurda traditsioone järgides folkloori esindusžanridele nagu regilaul, muistend, muinasjutt, jõuti - vastupidiselt nõukogude retoorilistele süüdistustele minevikupärandi tendentslikus eelistamises - huvi tunda ka marginaalia ja kaasaegsete teemade vastu (nt Anderson 1926), korraldati lastefolkloori kogumise kampaaniaid, kaasaegsete meetoditega uuriti jutustamist (Viidalepp 1937) jmt.

Nõukogude folkloori kogumise kampaania aastail 1948-1953 möödus Eestis oluliste tulemusteta. Kuna Nõukogude folkloor sisaldas lisaks kaasaegsetele ja poliitilistele teemadele ka kultuuriharrastust ja taidlust, jäi see mõiste eesti folkloristidele arusaamatuks ja sellest distantseeruti esimesel võimalusel (vt nt Oinas 1985; Kulasalu 2017). Ometi peaks selle käsitlemisel absurdi kõrval nägema ka värskendavat muutust, mis tõepoolest oleks võinud tuua uuendusi eesti folkloristika mõnevõrra kivistunud uurimisaladesse. 


\section{Eesti-Vene suhted rahvateaduste huviobjektina}

Uue, sovetliku folkloristika kehtestamisel vajati pidevat ja teravat vastandumist eelnevate perioodide uurijatele, selle käigus langes stalinistliku laine põhja (vrd Olesk 2003) isegi seni kogumisgeeniuseks nimetatud Jakob Hurt, rääkimata iseseisvuse-aegsetest folkloristikest teemadest (vrd Laugaste 1946 ja EKA 1953, 8).

Nagu ilmekalt on näha Viidalepa tsitaadist artikli alguses, nõudis ametlik ideoloogia eesti-vene suhete positiivsust - isegi kirjandusteoste ja rahvaluuleandmete võltsimise hinnaga (nt Tedre 2008, 136). Stalinismiaegsetes kirjutistes väideti, et "kodanlikus" teaduses varjati ja alavääristati eesti-vene rahvaste sõbralikke suhteid (EKA 1953, 8). Tõepoolest polnudki naaber- ja vähemusrahvaste folkloor sõjaeelses Eesti Vabariigis peavoolu kogumis- ja uurimisteema, kuid siiski ka mitte marginaalia. Piiri- ja üleminekualade kultuurisuhted on alati paelunud folkloristide tähelepanu, tänu Paul Ariste ja Oskar Looritsa isiklikele uurijahuvidele on vene rahvusvähemuse pärimust sisaldava ERA, Vene-nimelise käsikirjaseeria suurus märkimisväärsed 17 köidet ehk ligi 10000 lehekülge (vt Viidalepp 1986, 164; Salve 2002, 34-38).

Siiski tõstatati eesti-vene suhete teema peatselt pärast sõja lõppu. Otse loomulikult olid eesti haritlased kohustatud sisenema venekeelsesse teadusruumi ning tõlkima vene kirjandust, koheselt asuti välja andma vene-eesti sõnastikke (vt Ahven 2007, 30). Rahvusteaduste uurijad said eesti-vene suhete kohustuslikku teemat seostada etnogeneesi selgitamisega arheoloogia, etnograafia ja dialektoloogia andmete kogumise ja analüüsimise käigus (nt Moora 1956; Moora 1964). Ida-slaavi ja vene mõjusid rõhutati mitmetes ajaloo-alastes kirjutistes, Eesti ajalugu kirjeldati muistse Vene riigi ajaloo raames (nt ENSV 1957, 19-20, 30-32). Sealjuures jäeti läänemeresoomelised sidemed või skandinaavia, germaani ja balti suhted tahaplaanile või üldse mainimata.

Mõneti üllatavalt ei olnud 1940. aastate lõpu rahvaluule-alastes programmilistes artiklites vene teema üldse fookuses. Eduard Laugaste, kes täitis sõjajärgses eesti folkloristikas mitmeid juhtivaid rolle ja esines seetõttu uute seisukohtade avaldamisega, elas oma kirjutistes esialgu järel-eesti ajas ja kajastas uuenduslikke ülesandeid üsna tasakaalustatult (vt nt Laugaste 1945; 1947; 1950). 


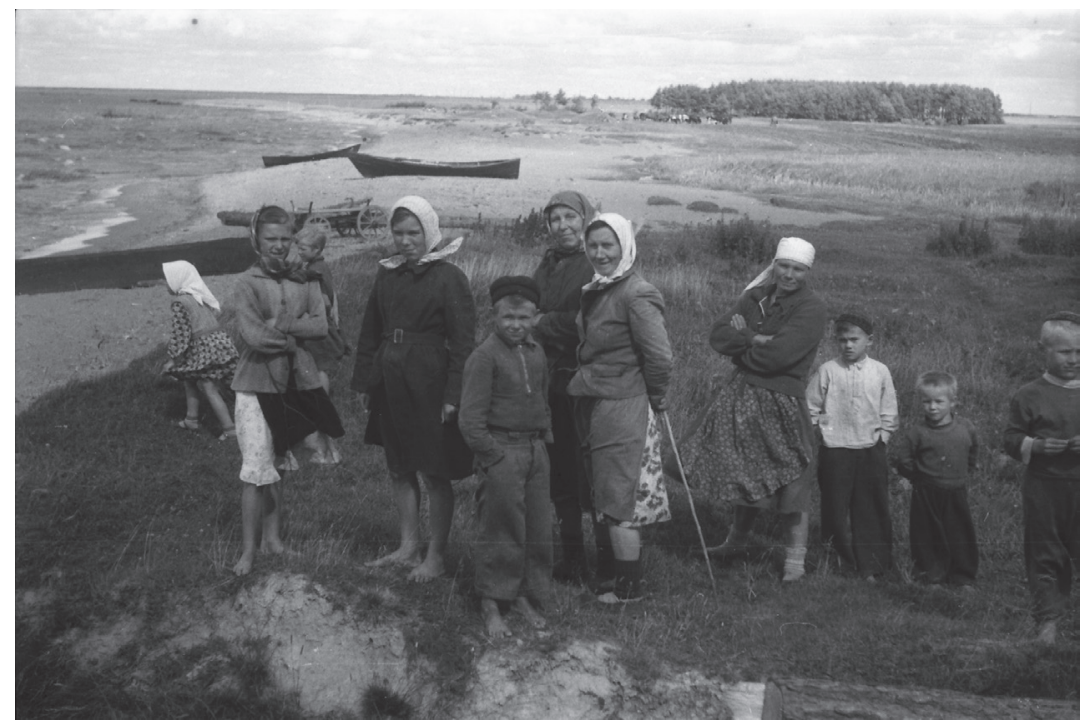

Jäädvustus Pepsitaguselt ekspeditsioonilt 1957. aastal.

Foto: Richard Viidalepp (KKI, Foto 630).

1948. aasta veebruaris Riiklikus Kirjandusmuuseumis toimunud muuseumialasel asutuste-vahelisel konverentsil ${ }^{5}$ tõstatas Erna Normann teema eesti-vene suhete kohta materjali kogumisest Peipsi rannikul. ${ }^{6}$ Kuid see teema on ettekande tekstis ainult üks lühike lause, mitte enamat - võrreldes pikkade ülevaadetega töölis- ja isamaasõja folkloori kogumisest. Konverentsi kokkuvõtvas ettekandes viitas Laugaste eesti-vene suhete teema käsilolevusele, kuid sedagi üldsõnaliselt. ${ }^{7}$ Kuigi konverentsi otsustes ${ }^{8}$ teemat ei kajastatud, esitati Kirjandusmuuseumi diskussioonikoosolekul (28. IV 1948)

${ }^{5}$ Konverentsi “Teadusliku uurimismaterjali kogumistöö probleeme ENSV TA Ühiskonnateaduste Osakonna asutistes" (28.-29. veebruaril) ning sellele järgnenud "Teadusliku uurimismaterjali korraldamistöö probleeme ENSV TA Ühiskonnateaduste Osakonna asutistes" (16.-17. oktoobril) ettekannete käsikirjalised tekstid ja vastuvõetud otsuste protokollid asuvad EKM arhiivis (F 24, n 1, s 112 ja 120).

${ }^{6} \mathrm{~F} 24, \mathrm{n} 1$, s 112 , lk 41.

$7 \mathrm{~F} 24, \mathrm{n} 1$, s 112 , lk 113.

${ }^{8}$ F 24, n 1, s 112, lk 117-120. 
konverentsi resolutsioonide teostumise kava, kus märgiti kogumistöö punkti all, et stipendiaadid saadetakse Petserimaale ja Peipsi rannikule vene folkloori koguma. Tõepoolest, käsikirjaseeria RKM, Vene kolmes esimeses köites on 1640 lehekülge üliõpilaste üleskirjutusi aastaist 1948-1949. ${ }^{9}$

1948. aasta aprillis toimunud Teaduste Akadeemia ühiskonnateaduste osakonna teadusliku sessiooni ettekannete katusteemaks oli "Eesti-Vene suhted ajalooliselt", seal esines Viidalepp ettekandega "Eesti-vene suhed folkloorses materjalis" ja Herbert Tampere "Eesti vene suhted eesti rahvamuusikas". ${ }^{10}$

\section{Kalevipoeg eesti folkloristika päästjana}

Stalinismi ajal tõusis Nõukogude folkloristikas fookusesse rahvaeepos. Nagu Nigol Andresen väljendus, nähti Kalevalas "karjala rahva suurt kollektiivset eepost" (Andresen 1949, 353). Just kollektiivne looming, rahvapärasus ja demokraatlik vaim olid märksõnad, mis vastasid nõukogude rahvalikkuse ideele (samas, 353-355). Laugaste kirjutas oma programmilises ajaleheartiklis 1950, et Kalevipoeg ja teised kangelased kehastasid rahvaloomingus rahva ootusi ja lootusi - väide, mida võis sobivalt Lenini tsitaadiga kinnitada (Laugaste 1950). Või nagu kirjutas Artur Vassar Eesti ja muistse Vene riigi suhteid puudutavas peatükis 1955. aastal ilmunud ENSV ajaloo esimeses osas:

Eesti rahvas on säilitanud helged mälestused Muistse Vene riigi aegadest oma rahvaluules. [---]. Lähedased jooned ühendavad eesti rahvakangelast Kalevipoega nn. Kiievi bõliinade vägilastega. Kalevipoja tihedas koostöös venelastega, juttudes silla ehitamisest üle Peipsi, vene abist linnade ehitamisel ning võitluses välisvaenlaste vastu - kõiges selles on eesti rahvas talletanud oma põlised ajaloolised kogemused oma ustavast sõbrast ja kaitsjast - vene rahvast. (ENSV $1955,101)$

Eeposte tähelennu üks põhjuseid oli ka sovetlikus kultuuripoliitikas, kus tõsteti esile rahva loomingulisust. Selle põhjuseks oli ühelt poolt lihtrahva (töörahva kui eelistatud klassi) prioriseerimine - kvaliteetseid ja "suure" sisuga kultuuritooteid ei nähtud ülemklasside privileegina, vaid laiadele töötavatele rahvamassidele omaste ja

${ }^{9}$ Kogujaiks Veera Voogla, Lydia Borovkova ja Olga Hildebrant.

${ }^{10}$ RKM 1948. a teaduslik tööaruanne (F 24, n 1, s 116, 18); vt ka Tampere 1949. 


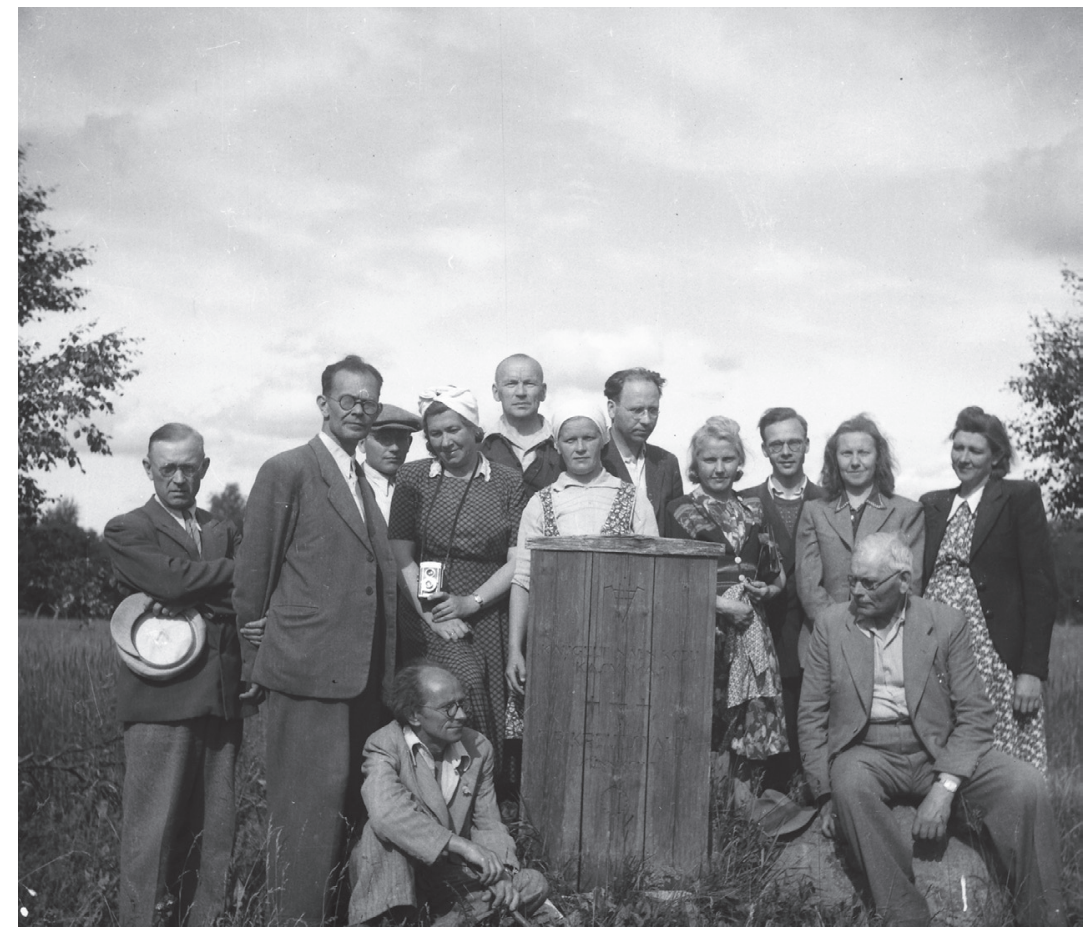

Kalevipoja ekspeditsiooni liikmed, kirjandusteadlased ja folkloristid Lauluisa sünnikoha varemeil. Tagant vasakult kolmas Eduard Laugaste, paremalt teine Helga Nõu, kolmas Udo Mägi, neljas Selma Lätt.

Foto: Richard Viidalepp, 1950 (KKI, Foto 377).

kättesaadavatena. Nõukogude ajal oli tuntud kurioosum rahvalaulikute kirjanike liitude liikmeks võtmine (vt nt Esmaspäev 1940).

100 aastat "Kalevala" ilmumisest 1949. aastal, Kreutzwaldi sünniaastapäev ja rahvuseepose "Kalevipoeg" juubeliks valmistumine ärgitasid eepose tõlkimist ning kommenteeritud ja täiendatud uustrükke (Ahven 2007, 80), mistõttu sai eeposest aastaiks folkloristide keskne huviobjekt. ${ }^{11}$ Tõlkimise ja kommenteerimise tarbeks oli põhjendatud ka vajadus koguda Kalevipoja pärimust. Kuna

${ }^{11}$ Algas nii demokraatlikuks kirjanikuks nimetatud Kreutzwaldi personaalia uurimine ja väljaandmine kui ka eepose "Kalevipoeg" igakülgne läbivalgustamine nii regilaule kui hiiumuistendeid allikaks võttes, vt nt Laugaste 1959; Tedre 2008. 
1950. aastate alguses ilmunud eepose uusväljaannete toimetaja, kommentaaride ja saatesõnade autor (nt Kreutzwald 1953) ning hiljem ka akadeemilise hiiupärimuse seeria koostaja ja toimetaja oli Tartu Riikliku Ülikooli eesti kirjanduse ja rahvaluule kateedri dotsent Eduard Laugaste, seati juba 1951. aastal Kalevipoja paigad tudengite kogumiseesmärgiks ja Virumaa kogumispraktika sihtkohaks. ${ }^{12} 1950$. teisel poolel akadeemiliste rahvaluulekogumike taasalustamise aegu võeti sihiks ka vägilasmuistendite publitseerimine. Erandlikuna eesti folkloristika ajaloos avaldatigi ammendavalt üks pärimusliik - hiiumuistendid. Monumenta Estoniae Antiquae II seeria koostati ja avaldati trükis toonaseid kirjastusolusid arvestades suhteliselt kiiresti - aastail 1959-1970. ${ }^{13}$

Seni edukaima eesti akadeemilise rahvaluuleseeria üks pante oli aktiivne kogumistöö. Vägilasmuistenditele pühendatud ekspeditsioonide sarjad toimusid kõikide rahvaluule kogumisega seotud institutsioonide osavõtul Lääne- ja Ida-Virumaale, Saaremaale ja Võrumaale - kohati käsikäes regilaulude päästeaktsioonidega. ${ }^{14}$

\section{Muutused välitööde sisus ja vormis}

Stalinismi ajal ei toimunud mitte ainult folkloori mõiste täitmine uue sisuga, vaid ka folkloori kogumise vormi uuendamine. Veel sõjajärgsel aastakümnel koguti Eestis rahvaluulet tavapäraselt ühekahekaupa retkel käies. 1940. aastate lõpul toimus uue nõukoguliku välitööde vormi introdutseerimine eesti rahvusteadustesse - pidulikult ekspeditsioonideks nimetatud välitööd viidi läbi (ideaalis) suure osavõtjate hulgaga, mitme eriala ja/või institutsiooni esindajatega, peamiselt mõnes maapiirkonnas. Selline liiasus kandis endas sovetlikule maailmakäsitlusele omast optimismi, uudismaade ja maardlate hõlvamise poeetikat. Rahvaluule kogumist nähti kui teadmiste tühjendavat ammutamist maapiirkondades, millele viitab kasutusse võetud termin "frontaalne kogumine". Kogumistöö "frontaalsuse" ${ }^{12}$ EKRK I 2, 349 - Anita Riis (1951). Siin ja edaspidi viidatud kogumispäevikud on kättesaadavad digiteeritult ja/või tekstistusena Eesti Kirjandusmuuseumi failirepositooriumis Kivike (kivike.kirmus.ee). Vt ka Laugaste \& Rõõm 1958.

13 "Muistendid Kalevipojast" (Laugaste \& Normann 1959), "Muistendid Suurest Tõllust ja teistest" (Laugaste \& Liiv \& Normann 1963) ning "Muistendid Vanapaganast" (Laugaste \& Liiv 1970).

${ }^{14}$ Vt sarjas "Rahvapärimuse koguja" ilmunud kogumisüleskutseid ja -ülevaateid, nt Liiv 1961; Lätt \& Tampere 1961; Tampere 1962. 
tagas see, et kaasati erinevate uurijahuvidega folkloristid ning naaberteaduste esindajad (muusikud, dialektoloogid, etnograafid), hõlmates kogu piirkonna suulise (ja ainelise) pärimuse, erinevad rahvaluule žanrid ja teemad..$^{15}$

Muutus välitööde vormis sai alguse 1948. aastal kirjandusmuuseumis toimunud juba eelpool mainitud konverentsidel, kus osalesid lisaks folkloristidele ka murdeuurijad ja etnograafid. Konverentside ettekannete ja sõnavõttude korduvaks sisuks oli kutse erinevate erialade teadlaste koostööle. Kuigi 1940. aastate lõpus toimusid mõned ekspeditsioonid Kihnu ja Setumaale, kus osalesidki mitme rahvusteaduse esindajad, jäi püsima koostöövorm, kus folkloristide välitöödel osales mõni muusik või muusikatudeng nootide kirjutajana. See oli ühelt poolt tingitud salvestusvahendite puudumisest (muusikat ei saanud muul moel jäädvustada), teisalt ka muusikute huvist rahvamuusika vastu (vt Saarlo 2017b).

Kuna fookusesse tõusnud hiiu- ja vägilasmuistendid olid ühised vene pärimusega - nii motiivide kui ka levikupiirkondade poolest, korraldati tolleaegseid välitöid eelistatult segarahvastikuga piirialadel Peipsi järve ümbruses: Alutagusel, Kodaveres ja Setumaal (Kümme aastat 1956, 190; ENSV TA 1965, 271; Tedre 1997, 202-204).

Toonaste ekspeditsioonide eesmärgid võtab väga hästi kokku oma 1952. aasta kogumispäevikus Salme Lõhmus, toonane kirjandusmuuseumi funktsionär (peavarahoidja ja direktori kohusetäitja), loetledes kogumiskonverentsidel püstitatud ülesandeid rahvaste vaheliste suhete ja kaasaegse "nõukogude folkloori" kohta.

Plaanis on meil 1) hankida materjali ristlevate etniliste rühmade (eestlased, setud ja mitmesuguse päritoluga venelased) rahvaluule kujunemise ja vastastikuste suhete selgitamiseks, 2) kirjutada üles rahva mälestusi tööstus- ja kaubanduskeskuste arenemisest ning ühes sellega jälgida töölisfolkloori ja revolutsiooniliste sündmuste kajastumist rahvaloomingus, 3) teha tähelepanekuid rahva elu-olu ja kunstilise loomingu ununemisest nõukogude ajal $j$. $m$.

(ERA, Vene, 379 < Räpina - Salme Lõhmus (1952))

Nii Setumaa ja Räpina (1948-1949 ja 1952) kui ka Kodavere (195455) ekspeditsioonide raames käisid vene keelt paremini valdavad kogujad, nagu Olli Jõgever, Salme Lõhmus ja Anatoli Garšnek paralleelselt eesti küladega ka vene rahvastikuga külades. Kuigi jäädvustati ka kombestikku ja ajaloolist pärimust, oli põhirõhk siiski muusikalisel folklooril.

${ }^{15}$ Välitööde muutustest vt nt Oras 2008, 60-62 ja 2009. 


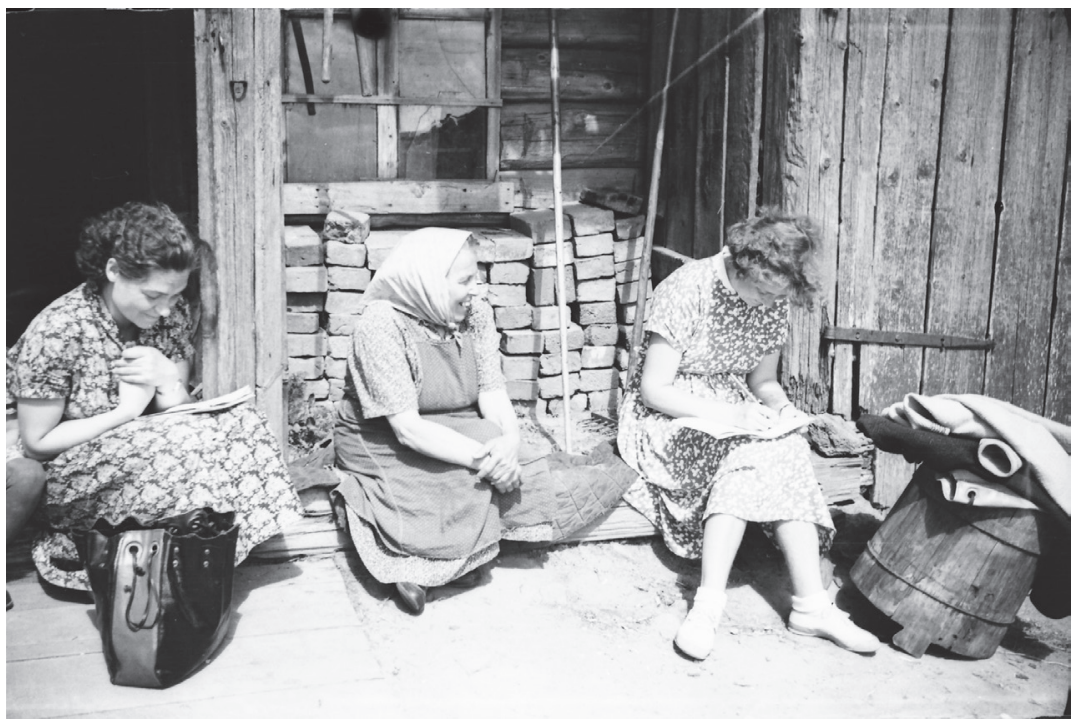

Aliide Paulilt Ohakvere külas pannakse kirja ja nooti mitmeid laule. Vasakul Veera Pino, paremal Ester Mägi. Foto: Loreida Raudsep, 1957 (KKI, Foto 547).

Sama päeva. s.o laupäeva õhtul pidi olema vene külas Lü̈̈bnitsas praasnik, tahtsime seda vaadata, pealegi polnud mina üldse vene külades käinud. [---] Praasniku nägemisest ei tulnud suurt midagi välja, kuigi oldi juba selle ootel. Siirdusime ühte peresse, kus osati vene rahvalaule, ning fonografeerisime neid. Kuna ma varem polnud vene laule kuulnud, jälgisin neid suure huviga.

(RKM II 28, $344<$ Räpina - Selma Lätt (1952))

Vene laulude jäädvustamise ärgitaja kirjandusmuuseumis oli Herbert Tampere oma laialdaste etnomusikoloogia-alaste teadmiste ja huviga. Siiski jäid vene folkloori talletamise ettevõtmised marginaalseks erandiks, vene materjali jäädvustati sõjaeelsega võrreldamatult vähem, materjalid arhiveeriti (tavade kohaselt) eraldi seerias RKM, Vene. Sellest kogumisteemast eemalduti vaikimisi, kui Tartu Riikliku Ülikooli vene keele kateeder hakkas 1960. aastatel alguses ise välitöid korraldama. ${ }^{16}$

16 Tartu Riikliku Ülikooli vene keele kateedri ja vene kirjanduse kateedri rahvaluulekogu TRÜ, VKK algatati 1961. aastal. 


\section{Keele ja Kirjanduse Instituudi rahvaluulesektori ekspeditsioonid Alutagusele}

KKI rahvaluulesektori 1950. aastate välitööd olid kantud kolmest omavahel põimuvast asjaolust: 1) ühisekspeditsioonide uudsusest; 2) eesti-vene suhete kajastuste dokumenteerimiseks rahvaloomingus eestlaste etnogeneesi uurimise eesmärgil ning 3) Kalevipoja pärimuse jäädvustamise soovist.

Toonastes ENSV Teaduste Akadeemia aruannetes ja ülevaadetes märgiti rahvaluulesektori aktiivset kogumistööd, kuid KKI käsikirjaseerias domineerisid aastail 1947-1954 üksikkogud. ${ }^{17}$ Sektori töötajad, Richard Viidalepp nende hulgas, võtsid osa ühisekspeditsioonidest Setumaale (1948-1949) ja Helmesse (1951), kuid sektori ühised välitööd algasid alles 1954. aastal Hiiumaa retkega - ja sealgi osalesid vaid Viidalepp ja Tedre. Suuremate välitööde puuduse põhjuseid võis olla mitmeid, alates juba töötajate nappusest, majanduslikest raskustest seoses TA instituutide kolimisega; samuti teaduslike ülesannete ja prioriteetide seadmisest instituudi juhtkonna poolt. ${ }^{18}$

KKI folkloristid käisid Ida-Virumaal välitöödel n-ö mitme lainena: aastatel 1955-1960 Richard Viidalepa juhtimisel Jõhvi, Iisaku ja Vaivara kihelkonnas, 1960. aastatel Ülo Tedre juhtimisel Lüganuses ja Jõhvis ning 1970. aastate lõpus Lüganuses nn järelkorjamistel. Järgnevalt tuleb juttu n-ö esimesest lainest, Richard Viidalepa juhitud ekspeditsioonidest.

Kogumisretkede tulemusena talletati 4165 lehekülge käsikirjalisi üleskirjutusi (ka vene ja poluvernikute küladest), 47 ühikut (486 pala) magnetofonisalvestusi ning tuhatkond fotot.

Kui algselt plaanitigi interdistsiplinaarseid (ja -institutsionaalseid) ekspeditsioone, kujunes siiski välja, et ekspeditsioonidel osalesid põhiliselt KKI töötajad ning mõnel aastal muusikud ja vene filoloogid.

Ekspeditsioone juhtis ja organiseeris Richard Viidalepp (19041986), liikmetena osalesid Loreida Raudsep (1922-2004), Helgi

${ }^{17}$ Näiteks Udo Mägi kogutud materjal Kodaverest ja Muhust köidetes KKI 1 ja 9 .

18 Äsja sektorijuhatajaks saanud Viidalepp märgib instituudi juhtkonna vastasust kogumistööle (KKI 27, 117). 


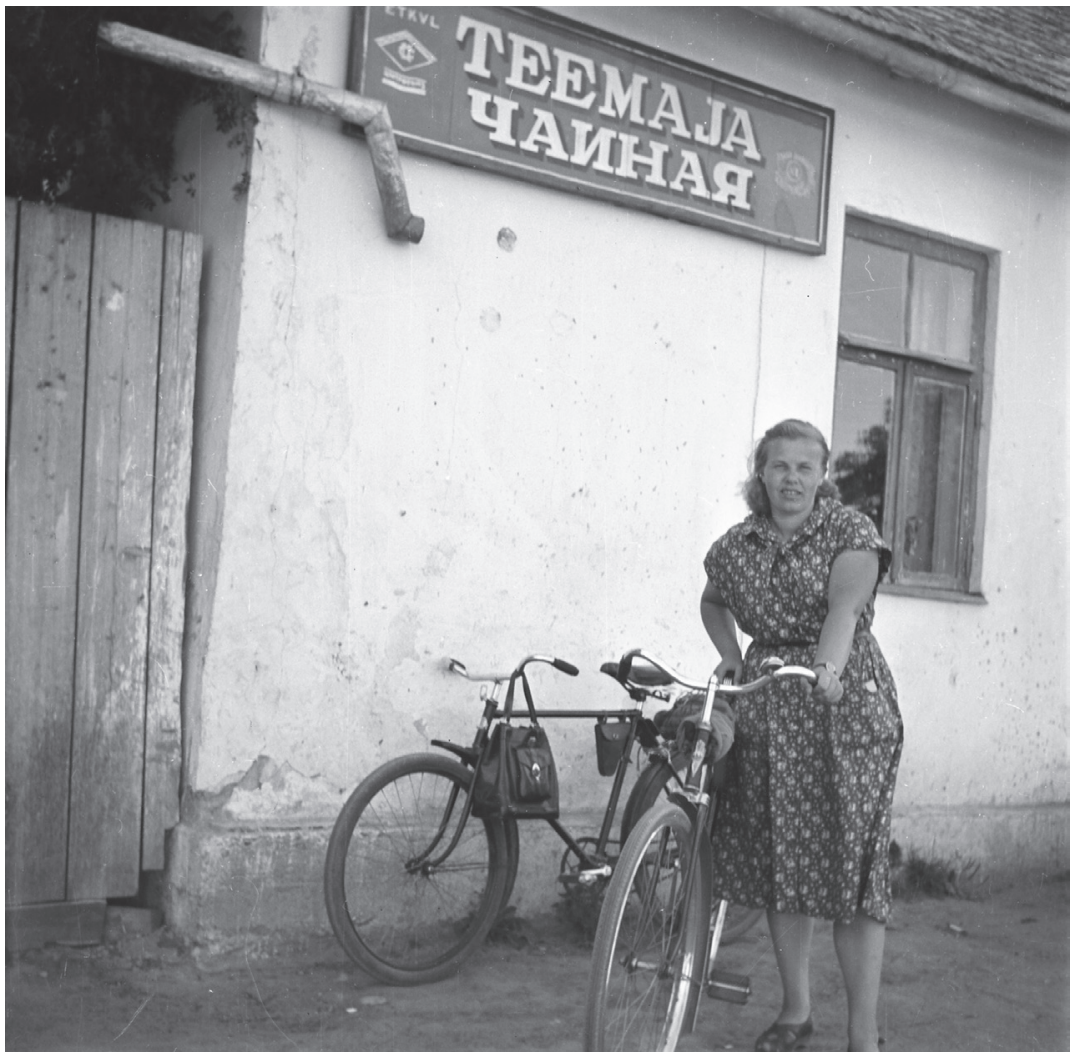

Loreida Raudsep Iisaku teemaja ees. Foto: Helgi Kihno, 1955 (KKI, Foto 441).

Kihno (1915-1993) ja Ülo Tedre (1028-2015); vähemal määral Veera Pino (1925-2015) ja Alviine Schmuul (snd 1934), Tallinna Konservatooriumist Vivian Jüris (snd 1932) ja Ester Mägi (snd 1922), KKIs kohakaaslasena töötanud literaat Jüri Šumakov (1914-1997) ning Tartu luuletaja ja pedagoog Veera Schmidt (1915-2000). ${ }^{19}$

Richard Viidalepp oli kogenud folklorist ja aktiivne rahvaluulekoguja. Eesti Rahvaluule Arhiivi ametnikuna 1929. aastast oli ta tegelenud ERA kaastööliste võrguga ning juhtinud mitmeid kogumisaktsioone. KKI rahvaluulesektorisse üleviiduna sai Viidalepp

${ }^{19}$ Ekspeditsioonide täpseid toimumisaegu ja osalejaid vt lisast 1. 


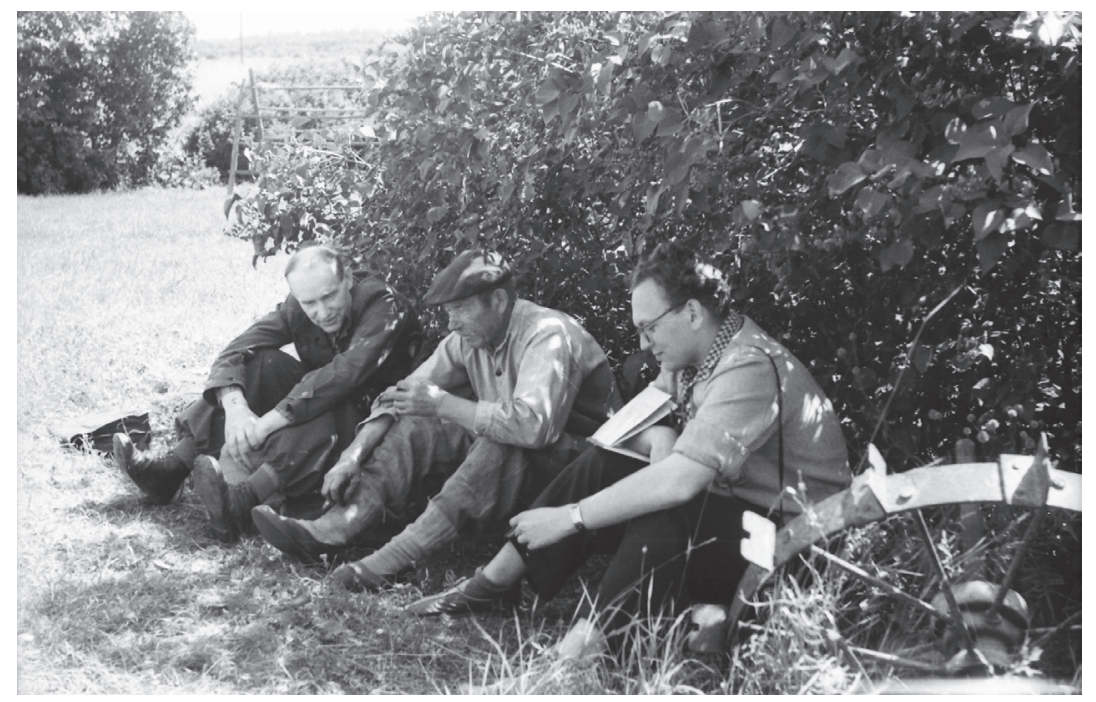

Richard Viidalepp ja Ülo Tedre küsitlemas Tudulinnas 1956. aastal. Foto: Richard Viidalepp (KKI, Foto 191).

pärast Instituudi Tallinna kolimist (1952) sektorijuhatajaks ning arvatavasti ka parema võimaluse kogumistööd korraldada ja uurimisteemasid valida.

Teised ekspeditsioonidel osalejad olid väga erinevate välitöökogemustega. Eesti filoloogia lõpetanutel oli välitööpraktika kõigil väljaõppe osa, neist Ülo Tedre ja Loreida Raudsepa praktika toimus nn kolhoosifolkloori kogumisajal 1950. aastate alguses. Kindlasti mõjutasid eelnevad kogemused ka Alutaguse ekspeditsioonide kogumismeetodeid ja -eelistusi. ${ }^{20}$

20 Ülo Tedre töötas KKI RS-s väikeste vahedega 1949. aastast, kaitses vahetult enne Alutaguse ekspeditsioone kandidaadiväitekirja lõppriimilisest rahvalaulust. Loreida Raudsep lõpetas Tartu Ülikooli 1952. aastal ja sai augustis partei suunamise kaudu KKI RS nooremaks teaduslikuks töötajaks. Helgi Kihno asus laborandina tööle 1953. aasta novembris. Veera Pino tuli KKI RS-e 1956. aastal pärast TRÜ aspirantuuri lõpetamist. Andmed KKI RS koosseisu kohta pärinevad Ahven 2007 vastavatest peatükkidest. 


\section{Välitööde eesmärgid, teemad ja meetodid}

KKI ekspeditsiooni eesmärgina märgib Ülo Tedre 1955. aastal:

Põhjuseks oli kompleksse ekspeditsiooni ettepanek (organisaator on Etnograafia Instituut Moskvas, prof. Tšebokšarovi juhendamisel uuritakse Balti rahvaste etnogeneesi) kuna Iisaku on eesti-vene segaala ja lisaks võimaliku vadja ( $\approx$ vai?) elemendiga. Sm. Viidalepp lootis lisaks leida ka täiendavaid andmeid oma töö jaoks eesti ja vene vägilasmuistendite ristumise kohta. ${ }^{21}$

Viidalepa juhitud ekspeditsioonid olidki erilised eelkõige kogumisala rahvastiku koosseisu tõttu. Viidalepa päeviku ${ }^{22}$ põhjal on ilmne, et temal oli selge arusaam välitööde piirkonna pärimusest ja rahvastikust - ta kirjutas palju poluvernikute traditsiooni jäädvustamisest.

Ülo Tedre on aastakümneid hiljem osutanud, et Alutaguse ekspeditsioonisarja eesmärk oli viimaste regilauljate jäädvustamine (Tedre 1999, 6), kuid Viidalepa erihuvide tõttu ei olnud muusikaline folkloor kindlasti sektori välitööde fookuses (Saarlo 2017a, 125-127). Pigem võibki neid välitöid iseloomustada frontaalsus. Viidalepp jagas osaliste vahel ülesanded, mis žanridele keegi keskendub - kuid see jaotus polnud loomulikult absoluutne. Kuigi Viidalepa kogujahuvi keskmes oli hiiupärimus, tegi ta kogenud rahvaluulekogujana enesestmõistetavalt märkmeid muusikalise folkloori kohta, nagu ka etnograafilisi, keelelisi, kultuuriloolisi jm tähelepanekuid. Tema vastutustunnet kogumistraditsioonide ja üldisemalt folkloristika ees näitab asjaolu, et helilindistamise algusaastail prevaleeris salvestiste seas muusikaline folkloor, sh regivärsiline rahvalaul.

Teised ekspeditsiooniliikmed ei olnud nii kogenud rahvaluulekogujad, neil ei väljendunud ka kindlat kogujahuvi. Noored folkloristid keskendusid nende jaoks silmapaistvatele ja eksootilistele nähtustele nagu käsikirjalised laulikud, pillimängijad, head jutustajad jne. Noorte kogujate kogumismeetodeid ja -eelistusi võis mõjustada ka eelnev kogemus - nad olid tudengite kogumispraktika läbinud 1950. aastate alul kolhoosides nn kolhoosifolkloori kogudes, mis

${ }^{21}$ KKI 20, 315. Etno- ja toponüümide vadja- ja vai- suhted olid arutelu-aines toonastes Eesti etnilise ajaloo uuringutes (nt Ariste 1965; Pall 1977, 228230), tänapäevaseks ülevaateks vt nt märksõnu Vaiga, Vaivara, Vaivina Kohanimeraamatust (Kallasmaa et al. 2016, 718-720) ning Ligi 2013, 18. ${ }^{22}$ Iisaku ekspeditsioonilt 1955 (KKI 20, 355/437). Virumaa ekspeditsioonipäevikute loendit vt lisa 2. 

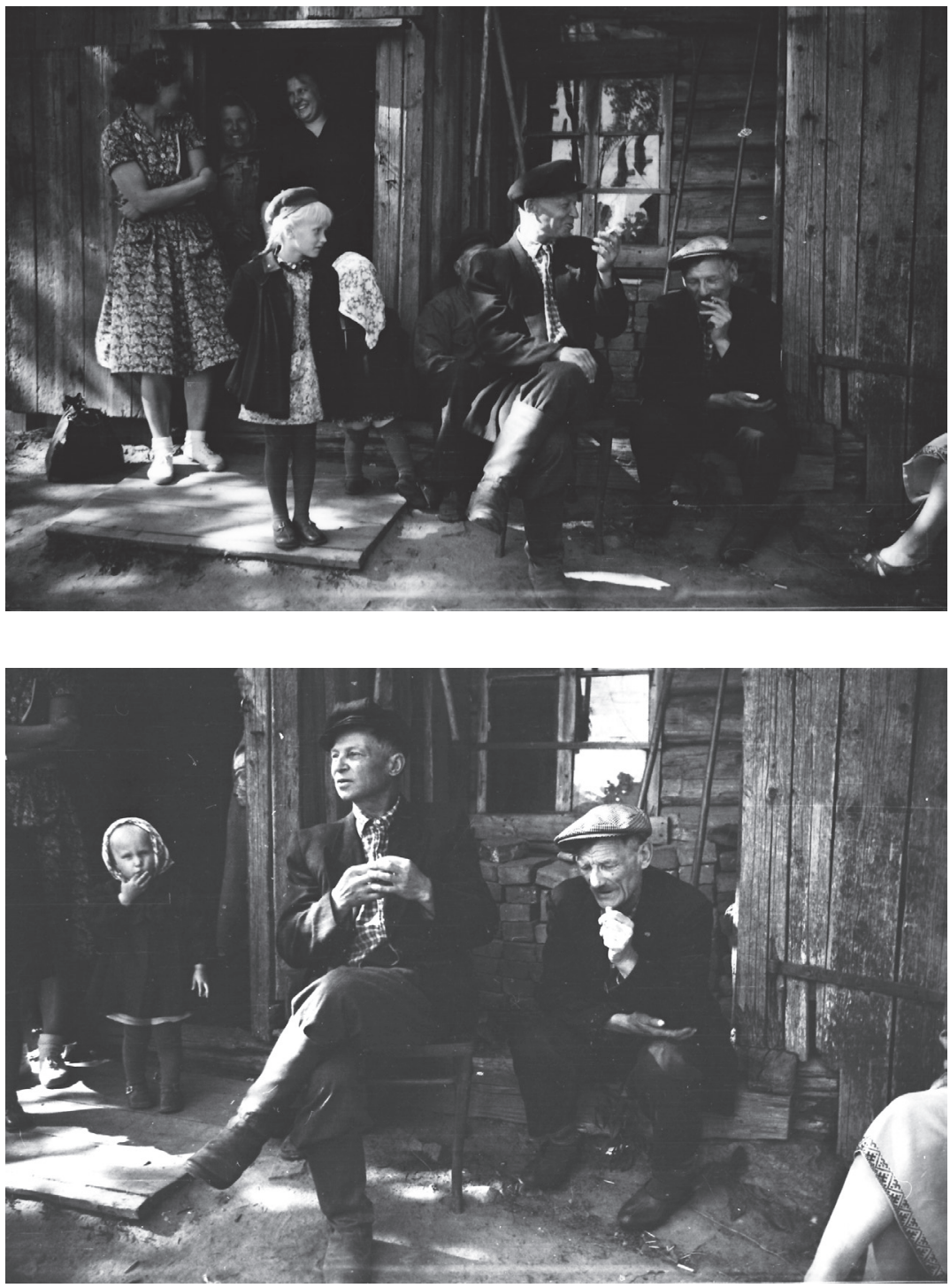

Ohakvere küla jutu- ja naljamehed Aleks Koppel ja Meinhard Vilumets on hoos. Fotod: Loreida Raudsep, 1957 (KKI, Foto 551-552). 
tähendas suures osas kolhooside majandustegevuse, kultuurilise harrastuse, seinalehtede ja punanurkade sisu, kujunduse ja muu sarnase harrastuskultuuri ja institutsionaalse kultuuri vahelmise fikseerimist, mistõttu nende tähelepanu võiski harjumuspäraselt olla suunatud pigem kultuuriajaloole ja kirjalikule väljendusele. Samuti võis olla köitvam noorusliku uljusega jahtida laulukladesid ja vastupuiklevaid pillimehi kui küsitleda kannatlikult näiteks kalendrikombestiku üksikasju, mille käigus ehk meenuks regivärsiliste tavandilaulude riismeid.

Omaette küsimus on, kuidas tulid kogujad toime uue ekspeditsioonilise välitöövormiga. Kollektiivsus, mis oli toona valitsevas retoorikas nii hinnatud, ei olnud alati lihtne ja kõigile sobiv lahendus. Kõigi osalejate eelnevad välitööd olid toimunud üksi-paarikesi muutuva peatuskohaga retkedena. Nüüd oli ekspeditsioonist osavõtjate arv suur, kogujate teed ristusid samas piirkonnas, suhelda tuli nõukogude ametnikega, administratiivselt oli kokku lepitud kindel peatuskoht jne. Uus välitööde korraldus kindlasti institutsionaliseeris ja formaliseeris nii folkloristide omavahelisi vahekordi kui ka suhteid informantidega.

Richard Viidalepp võttis välitööde juhina oma ülesannet väga tõsiselt ja üritas kõike organiseerida-korraldada eeskujulikus vormis. Juba esimesel ekspeditsioonil 1955. aastal peab ta töökoosolekuid, jagab üldisemaid kogumisülesandeid jmt (vt nt KKI 20, 371/2, 382). Siiski on Viidalepp hädas noorte kogujatega, kes tema soovitusi ei järgi ja isepäiselt oma valikuid teevad.

Sel päeval oli kavatsus Peipsi ääres ära käia, s.t Peipsi äärsetes külades. Ma kujutlesin, et me lähme sinna kogu kollektiiviga, et lähme korraga. Kuid nii see ei tulnud välja. [---] Olin endale pahane, et ma siiski ei kasutanud sel hommikul aktiivsemat veenmismeetodit. Meil oleks siiski olnud vaja see retk teha ära koos kogu kollektiiviga. Nü̈d kujunes asi teisiti ja see mõnevõrra kahjustas meie tööd. (KKI $20,391 / 2$ )

Ühe metsa vahel tulid vastu sm-d Raudsep ja Kihno - jalgratastel. Nemad olid nü̈̈d omakord minemas Peipsi äärde. Kokkusattumine oli rõómustav. Mulle oli see ootamatugi: ei teadnud, et nad üldse seda teed mööda võiksid tulla. Vahetasime lühidalt informatsiooni ja jätkasime teed.

Edasi minnes pidin jälle muretsevalt mõtlema, kuidas need eriaegsed retked siiski segavad meie tööd. Meil on ees veel käigud Kuremäele. 
Paratamatult tulevad needki teha vähemalt kahes grupis. Nii läheb meil tõepoolest üsna raskeks regulaarselt neljakesi kokku saada. See oleks aga väga tarvilik ekspeditsiooni töö teadlikumaks juhtimiseks ja suunamiseks. (KKI 20, 401/2)

Siiski on nii Viidalepa enese kui ka teiste osaliste päevikutest aru saada, et Viidalepp ise ei kohanenud kollektiivse kogumisvormiga ja eelistas oma plaane ja käike ise seada. See asetas aga noored folkloristid olukorda, kus nad jäid piisava juhenduseta.

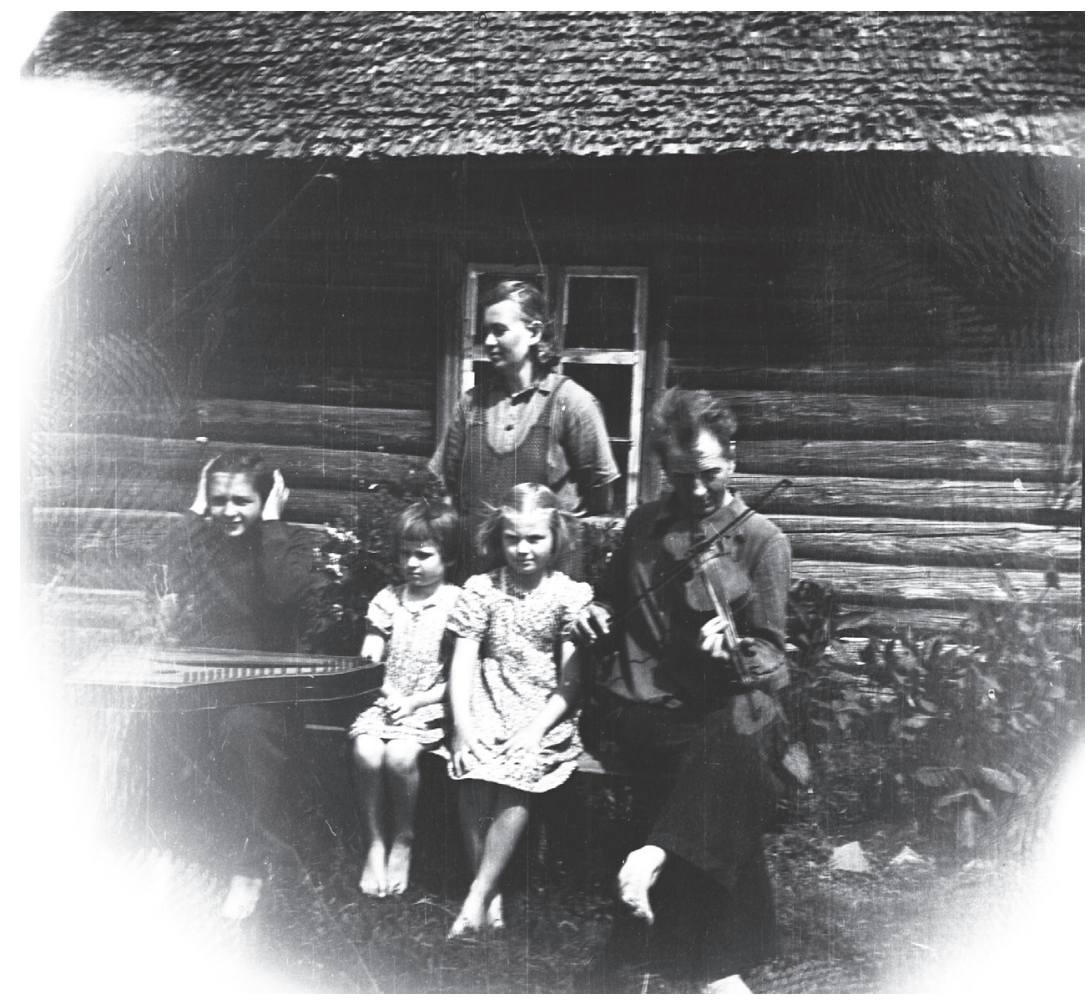

Pillimees Voldemar Kang Kõnnu külast oma perekonnaga.

Foto: Helgi Kihno, 1957 (KKI, Foto 403). 
Oleksin meelsasti läinud sm. Viidalepaga koos - tema on vilunud koguja mitmekümne aastase staažiga, kuid Viidalepp kadus hommikul koos rattaga. Jala ei jõudnud kuidagi jörele. Nii nurjus esimene katse taotleda kogemuste vahetamist konkreetse töö juures. [---]

Ekspeditsioon - minu osas - osalt ebaõnnestus. Objekte ja seega materjali vähe. Osalt oli see tingitud ebaküllaldasest ettevalmistusest. Puudus eelnev kirjalik kontakt kohalike kooliõpetajatega, kes oleksid võinud teha ettevalmistusi ja nö. "luuret". Ei saanud tutvuda sm. Viidalepa kogumismeetodiga. Jalgratta puudumise tõttu olin teistest isoleeritud ja määratud iseseisvale tööle. Kogemusi seetõttu sai nagu vähevõitu, igatahes oodatust vähem. Üksi kogumine - pealegi väljasõidul - nõuab kahtlemata suuremat ettevalmistust ja suuremaid kogemusi kui need minul on. Igatahes peab märkima, et senistest kogumismatkadest on see andmete ja materjalide suhtes kõige kasinam. (KKI 20, 318/9, 323 - Ülo Tedre (1955))

Arvatavasti jõudis see vaikiv konflikt KKI juhtkonnani ja selle tagajärjeks oli Viidalepa 1956. aasta päeviku muutumine silmnähtavalt ametlikumaks ja aruandlikumaks. Ta alustab ekspeditsiooni korraldamise ja ettevalmistuste ülevaatega ning viib sisse mitmesuguseid uuendusi, nagu igahommikused nõupidamised, kogumisaruanded jmt. Muutusi päeviku kirjastiilis ja töökorralduses kajastab ilmekalt esimese tööpäeva alguse kirjeldus:

Sel hommikul enne tööle minemist tegin omavahelise nõupidamise, milles ekspeditsiooni liikmeile selgitasin meie ees seisvaid ülesandeid ja nende lahendamise võimalusi.

Muu seas ütlesin:

"Meie ülesandeks on uurida siinset rahvaloomingut, sõnalist ja muusikalist, nii endisaegset kui kaasaegset. On vaja selgitada siinse folkloori kohalikke erijooni ja arengu eri suundi. On vaja jälgida nähtusi nende alalises muutumises ja ümberkujunemises. Mis on siin vana ja mis uus? Millal on tekkinud muutused?

Meil tuleb ekspeditsioonilisse töösse suhtuda mitte lihtsalt kogujatena, kes kirjutab kõike, mis ette juhtub, vaid uurijatena, kes suhtuvad kogutavasse ainestikku teadlikult ja hindavalt.

Mida siit saada võib, seda me veel ei tea, kuid juba täna õhtul oleme selles suhtes targemad ja teadlikumad.

Kohaliku rahvaga pü̈̈ame hästi läbi ajada.

Tekkinud raskustest ja äpardustest palun mind alati informeerida. Samuti palun esitada soove abistamise suhtes.

Meie huvipiirkonda kuuluvad järgmised ainealad: rahvalaulud (vanad ja uued), rahvajutud, mõistatused, vanasõnad ja kõnekäänud, uskumused ja kombed, rahvamuusika, rahvamängud. 
Kirjapanekuid teeme kuuldeliselt, paremad palad aga võtame helilindile."

Jagasin välja küsimuslehti.

Leppisime üldjoones kokku ka ülesannete jaotuse kohta:

Jüris - viisid, rahvamuusika ajalugu.

Kihno-mängud, laulud.

Raudsep-rahvasatiir, laulikud, tähtpäevade kombed ja laulud.

Tedre - uuem rahvalooming.

Viidalepp-eesti-vene suhted, jutustamine ja jutustamise kohalik spetsiifika.

Viidalepp Jaan - poistemängud, fotod.

Et me käime mitmes grupis, seadsin sisse üldise päeviku, mis seisab suures toas laual: igaüks märgib sisse, kuhu ja millal ta on läinud ja millal tagasi saabunud, võimalikult ka päeva esialgsed tulemused.

Teatasin mõned võimalikud objektid, kelle kohta oli juba andmeid.

Niisuguseid nõupidamisi toimus ka mitmel teisel hommikul, ms. ka selleks, et juhtida tähelepanu mõnede kohalike omapärasuste jälgimise vajadusele (seamatus, kuiva haugi söömine jm. ${ }^{23}$. (KKI $22,576 / 9)$

Tegelikkuses, loomulikult, ekspeditsiooni töökorraldus nii drastiliselt ei muutunud. Küll aga muutus Viidalepp ise koostööaltimaks ja kaasas aktiivsemalt teisi kogujaid oma plaanidesse-tegemistesse. Aastate jooksul õppisid kõik sujuvamat ühistööd, kujunesid välja kollektiivse kogumistöö voorused - info jagamine, üksteise teemade küsitlemine ja motiivide kontrollimine suuremalt maa-alalt jmt. Siiski lõppesid KKI folkloristide ühised käigud, Viidalepp jäi Alutagusele ja Peipsi-tagustele aladele käima koos mõne tehnikuga, kellest nt Helgi Kihnoga kujunes tal väga hea koostöö.

Kogumismeetodina valitses esimestel aastatel suuline küsitlus, mis palade kaupa üles kirjutati. Piirkonda sõites võeti ühendust ametiasutustega (kolhoosikeskus, külanõukogu), kus - lisaks möödapääsmatule komandeeringudokumentide tembeldamisele ja elukoha registreerimisele - püüti selgeks teha vanemate ja jutu- või lauluosavamate elanike elukohad. Sarnaselt teotseti ka külades, kus inimesi üles otsides selgitati välja informantide repertuaari iseloom ja suurus, otsiti pillimängijaid, käsikirjalisi laulukladesid jms.

${ }^{23}$ Seamatus oli Alutagusele omane seatapu-kombestik (vt nt KKI 22, 493/4 (82)), kuiva haugi söödi paastumaarjapäeval kalaõnne soodustamiseks Peipsi ümbruses (vt Hiiemäe 2013, 114-115). 
Tagantjärele hinnates kohati isegi ootuspärasest vähem umbusku, kuid päevikutes on jäädvustatud mõned vahejuhtumid, nagu laulukladede otsimine, tühjad majad, isikute põlvnemine ja pereliikmete saatus, mis viitavad äsjastele repressioonidele ja rasketele majanduslikele oludele.

Asume tagasiteele Kõrvemetsa poole, et otsida mitmelt poolt juhatatud laulukaustikut, mis pidavat asuma Aadami talus. Seal aga ei teata sellest midagi... (KKI 22, 47 - Loreida Raudsep (1956))

Peab ka märkima, et rahvas on mõneti kartlik või umbusklik. Eriti ilmneb see nimede n.ö pelgamises. Mitmed küsitletud isikud lihtsalt keeldusid ütlemast oma nimesid. Otsustades rahva juttude järgi, võib see tulla ka mõnede kolhoosiesimeeste (näit. "Tee kommunismile" esimees) väärast käitumisest. (KKI 20, 321 - Ülo Tedre (1955))

Alates teisest ekspeditsioonist 1956. aastal, olid välitöödel kasutada ka lintmagnetofonid (vt Oras 2009). Nii kujunesid ka suulised intervjuud aina rohkem helilindistamise ettevalmistuseks, repertuaari piiritlemiseks ja valimiseks. Kuna lintmagnetofonid polnud portatiivsed ja sõltusid elektrivoolu olemasolust, langes välitöötajate õlule kohustus organiseerida koht ja aeg helilindistamiseks ning veelgi keerulisem ülesanne saavutada üksmeel informantidega neis asjus. Transpordiolud olid rasked (või olematud) ja enamik inimesi kolhoositööga hõivatud, mistõttu ongi folkloristide päevikud tulvil logistikaprobleeme ja petetud lootusi.

14. juulil oli ette nähtud kibe tööpäev. Pidi tulema palju inimesi lindistamiseks. Läksin kohe peale hommikusööki metskonda, kerisin "Jauza" ketastelt täislindid suure magnetofoni ketastele ja täitsin kettad tühja lindiga. Valvasin seal kella 16-neni.

Siis vahetati mind välja. Tegin Helle ja Jaaniga sõidu järvele. Tulime tagasi kella 17.30ks - ei ühtegi objekti. Sm. Viidalepp kogus metskonna töötajad kokku, demonstreerisime neile kohapeal tehtud võtteid ja ka varasemaid. Hiljem pakkisime aparaadid ja siirdusime koju.

Õhtusöömaaeg oli kurb ja sünge. Kes oli kellele mida teinud??? (KKI 25, 16/8 - Helgi Kihno (1957))

Alates neljandast ekspeditsioonist 1958. aastal, kui ekspeditsiooniliikmete arv vähenes kahe-kolmeni, keskendusidki Viidalepp ja Kihno kohapärimuse helisalvestamisele, jäädvustades enamasti 
varem kohatud informantide repertuaari. Ekspeditsiooni kestvus kahanes, liiguti autoga, tänu millele sai külastada rohkem informante, samuti lahenesid transpordiprobleemid. Käsikirjalised üleskirjutused muutusid väga napiks. Enam ei saanudki rääkida kogumise frontaalsusest, tegu oli pigem materjali süvendatud järelkorjamisega.

\section{Kalevipoeg ja Dobrõnja}

Alutaguse oli etniliste suhete uurimiseks äärmiselt põnev ja viljakas piirkond, kuna sinna oli aastasadade jooksul ümbritsevatelt aladelt siirdunud erineva etnilise päritoluga elanikke. Üks Alutaguse põliseid etnilisi rühmi olid nn poluvernikud (ka poluvertsikud, Iisaku eestlased - vt Moora 1964, 11). Poluvernikute esivanemateks arvatakse teise aastatuhande jooksul mitme lainena Alutagusele jõudnud vadjalasi, kes segunesid sinna hiljem siirdunud venelastega (või venestunud vadjalastega) ning rääkisid omapärast eesti-vene segakeelt (Ligi 2013, 16-17). Poluvernikud võtsid omaks luteri usu ja läksid 20. sajandi jooksul üle eesti keelele (Moora 1964; vt ka Salve 2013, 148-149).

Sõja eel oli Alutagusel kogumisretkel käinud Paul Ariste (vt Ariste 1930), nõukogude ajal korraldasid uurimisretki etnograafid (Moora 1964). Kuna etniliste suhete alase materjali kogumine ja uurimine oli prioriteetne ja prestiižne, võiks eeldada ka Viidalepa korraldatud ekspeditsioonidelt kõigi või vähemalt enamiku osalejate keskendumist poluvernikute küsitlemisele.

Huvitaval kombel aga Viidalepp n-ö broneeris poluvernikute ja eesti-vene suhete teema endale ega rakendanud näiteks Loreida Raudsepat eesti-vene folkloori kogujana. Toona oli täitsa tavaline, et folkloriste takistas keeleoskamatus, mistõttu vene küladesse saadeti väheseid keeleoskajaid. Raudsep oli veetnud sõja-aastad vene tagalas (Uuet 2010, 103) ja valdas vabalt vene keelt, asudes vajadusel innukalt tõlgiks.

[kolhoosikontorisse] Sisse astub veel keegi võõras mees, kes pöördub vene keeles esimehe poole. Kuna parajasti pole kedagi, kes seda keelt mõistab, siis olen tõlgiks. (KKI 22, 25 - Loreida Raudsep (1956)) 


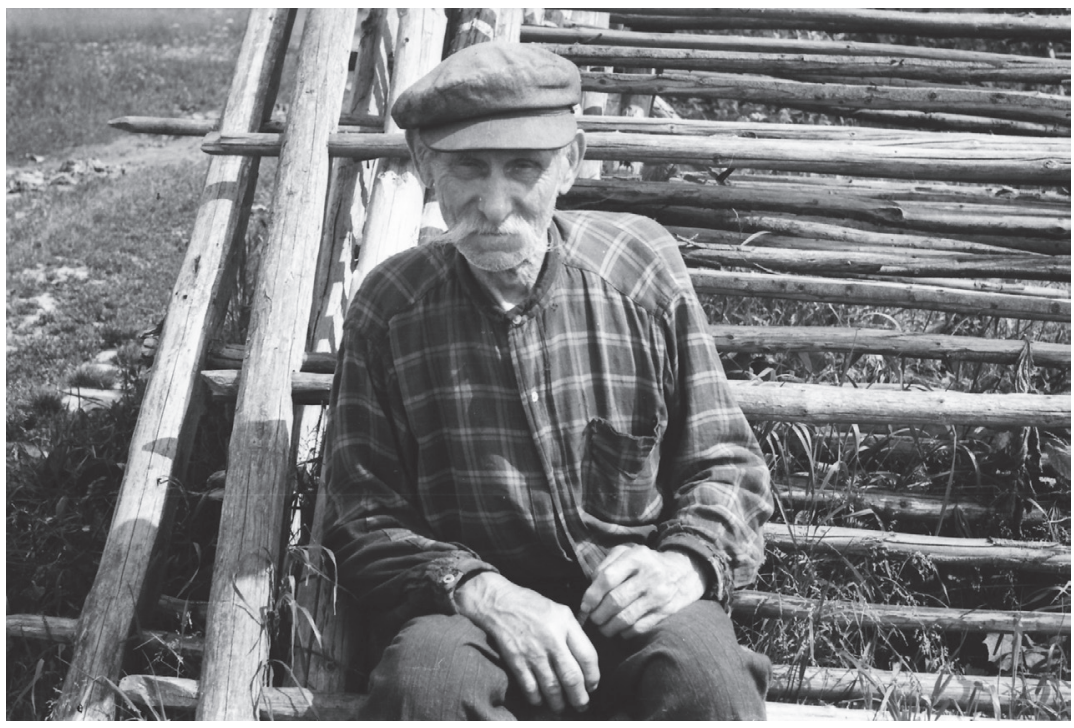

Poluverniku päritolu jutustaja Taavet Karp Vaikla külast. Foto: Richard Viidalepp, 1955 (KKI, Foto 60).

Ometi ei näita Raudsep mingit initsiatiivi eesti-vene suhete teema täitmiseks - ta ei käi vene külades kogumas, isegi Peipsi äärde sattudes ei kirjuta ta midagi üles vene peredest. Raudsep ei pane Iisaku poluvernikuid nagu õieti tähelegi, kuigi külastab ka seda päritolu inimesi ja imestleb eesti-vene segakeelt:

Oleme Kuremäe nimelises külas ja samanimelises kolhoosis Tukk'ide peres. Vanakesed elavad kahekesi. Liisal on 74, Jaanil aga juba 77 aastat turjal. Mõlemad on varem elanud Peipsi taga, Naroova jõe ääres. Siia asunud alles pärast sõda. Mees on kolhoosis sepaks, naine aga juba 6 aastat postivedajaks. Kõnelevad vabalt nii eesti kui ka vene keelt. Koera ja kassiga (rohkem loomi neil pole) räägivad nad vene keelt, omavahel aga vist mõlemat. [---] Lauldes on tunda venepärane aktsent. [---] Huvitav paar. Omavahel näib valitsevat väga südamlik vahekord ja täielik teineteise mõistmine. Nende keel kutsub vahetevahel meie huultele muige - see on kohati mingi keelepudru - eesti keel venekeelsete sõnadega, mis vägisi tikuvad kõnesse, eriti intensiivse mõtteviisi juures. (KKI 26, 19/21) 


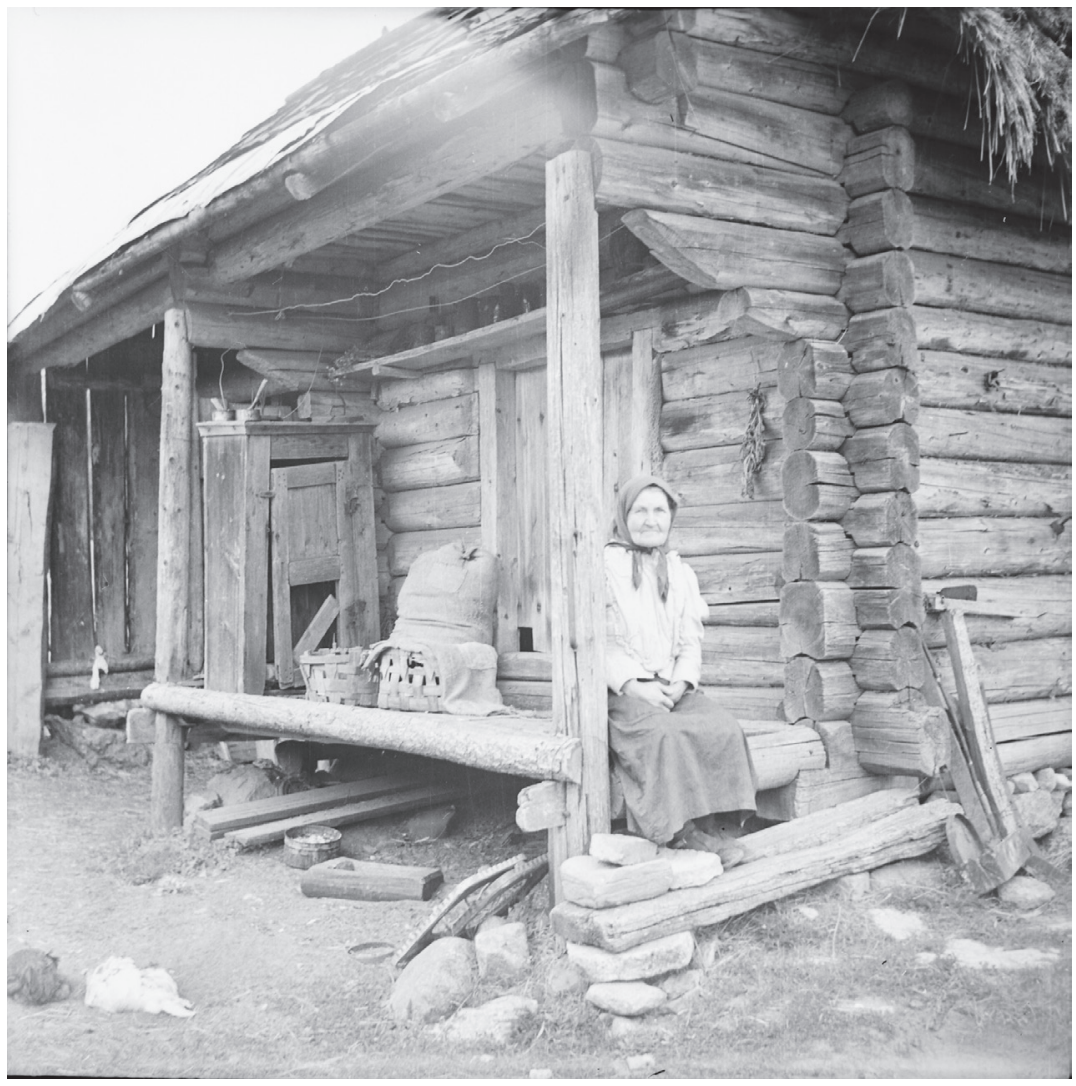

Sootaga külas oma aidatrepil istub Loviisa Mahmastol, poluverniku päritolu, ümbruskonnas tunnustatud ravitseja, suurepärane jutustaja ja laulja. Foto: Helgi Kihno, 1957 (KKI, Foto 1108).

Mis põhjused selle taga ka olid, on ilmselge, et Raudsep ei sobitunud Viidalepa tööstiiliga. Saanud endale kirikuvastase huumori näol isikliku uurimisteema, pühendus Loreida Raudsep edaspidi selle kogumisele Kesk-Eestist ja Hiiumaalt ning jäi Virumaa retkedelt kõrvale. Ka ei avaldanud ta Virumaa ekspeditsioonidega seoses kirjutisi. Tema kogumisstiili Järva- ja Hiiumaal iseloomustab hoog- 
töölisus - autoga külastati kiirkorras pastorinaljade jutustajaid ja lindistati nende repertuaari. ${ }^{24}$

Richard Viidalepp ise kogus huviga poluvernikute külades, nagu esialgselt plaanis oligi. Ta märkis poluvernikute keelevahetust, kuna see oli hästi dokumenteeritav: poluvernikud ise rääkisid, kuidas toimus üleminek vene keelelt eesti keelele paari põlvkonna jooksul. Ta täheldas ka eesti ja vene kommete erisusi, rahvausundilist ja etnograafilist terminoloogiat ning eestipärasuste sissetungi, nimevahetusi jms.

Valisin Vaikla (end. Porskova) küla. Kuulduste järgi peab just see olema nn. poluvernikute keskus. (KKI 20,363/4)

Ilma erilise sissejuhatuseta kuulsin temalt üht-teist rahvakommete alalt. Sain iseloomustuse ka rahvuslike olude kohta, andmeid küla laialiajamise kohta jne. Iseloomulik oli ka jutustaja enda keelepruuk ja venepärane sõnastus. "Praegust ka isekeskis suuremast vene keelt räägivadki," ütles ta selle küla kohta. Seda ma kuulsin ise ka oma kõrvaga, et vanemad inimesed kõnelevad parema meelega vene keelt, noortel aga domineerib eesti keel. (KKI 20,367/8)

T. Murumäe ütleb enda kohta: "Ennem isakodus kodune keel oli vene keel. Aga kui meie juba lapsed saime, siis juba eestlased. Naine oli ka siit." [---]

Küsisin temalt uskumusi ja kombeid. Huvitav oli teade külmale ohverdamisest talvel, et herned suvel head saaki kannaksid. Kuulsin teate mütoloogilisest olendist, kelle nimi oli xyдóü25. Tema mütol. terminoloogia oligi osalt eesti, osalt vene keeles. (KKI 20, 370/1)

Kuid vene külasid ja peresid Viidalepp vältis. Peipsiäärsetest vene küladest pöördus tagasi põhjendusega, et vene peredest pole midagi koguda. Sellega järgis ta endiselt n-ö traditsiooni puhtuse printsiipi, mis valitses eesti folkloristikas pea 20. sajandi lõpuni: "päris folkloori" kannavad ikka põliselanikud, sisserännanute folkloor ei ole relevantne.

Alaküla on suur vene küla. Külas on kirik. On ka kauplus, mis aga esmasp. tõttu suletud. Küla on üsna suur, kuid jätab siiski kuidagi

${ }^{24}$ Järvamaa ekspeditsioon toimus 1958. aastal (KKI 29), Hiiumaa 1959 (KKI 30). Raudsep osales ka 1965. aastal Järvamaal KKI suuremal ekspeditsioonil (KKI 38).

${ }^{25}$ xyдóŭ - luupainaja, vt KKI 20, 577 (100). 
kõleda mulje - vähe on puid, vähe on rohelist, aedu majade ümber. Sattusin korduvalt venelaste majadesse ega saanud paberile midagi. (KKI 20, 400)

1957. ja 1958. aastal olidki ekspeditsioonil seetõttu kaasas vene materjali kogumiseks vene filoloogid-kirjanikud Jüri Šumakov ja Veera Schmidt. ${ }^{26}$ Siiski ei olnud Viidalepp ka sellise koostööga rahul. Šumakov, kel oli Peipsi-äärses piirkonnas palju tuttavaid, tegutses liiga isepäiselt ja Viidalepa jaoks vististi kontrollimatult. Sellest hoolimata jätkus nende (konfliktne) koostöö ka hilisematel ekspeditsioonidel Peipsi teisel kaldal.

Sõidame kloostri juurde Šumakovi otsima, sest ta jäi sinna ennem maha, et koguda andmeid võimalike vene jutustajate kohta. Leian Š. kloostri kirikust, kus parajasti toimub teenistus. Ta ei soovigi Illukale tulla, vaid soovib ööbida siin kellegi tuttava pool. (KKI 32, 449/50)

Soompea külas Zabolotnaja juures. Šumakov hakkas siin pihta vene keelega, kuid paistis, et see pahandas vanainimese ära, sest ta peab ennast eestlaseks. On sündinud Luuga külas. Mõne asja kohta ütleb: “Это в русских деревнях, а у нас не было." (KKI 32, 473)27

Veera Schmidtil puudusid Viidalepa arvates (ja küllap ka tegelikkuses) välitööde kogemused, mistõttu ta ei süvenenud küllaldaselt kogumistöösse.

Siis selgus, et sm. Schmidt, kellelt hommikul sain telefonogrammi, oli juba Vasknarvast tagasi. Tundus, et ta nähtavasti tegi oma töö liiga lühidalt. Oli ju kokku lepitud, et ta alles laupäeval pidi tulema tagasi. [---]

Pidasin nõu sm. Schmidtiga tema ärasõidu asjus. Ühtlasi kuulsin informatsiooni tema käigu tulemuste kohta. Ta tulemused pole kuigi suured. Nähtavasti oleksin pidanud temaga kaasas olema ja aitama küsitleda. Kuid see polnud võimalik, sest ma pidin samal ajal siin olema, et organiseerida lindistamist. (KKI 24, 241/2 - Richard Viidalepp (1958))

Schmidtiga suheldes avaldusid eredalt Viidalepa isiksuse vastuolud. Ta oli kui lõhki rebitud vastutuse ja kohusetunde koorma all.

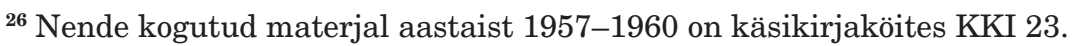
Kahjuks ei kirjutanud kumbki välitööpäevikut.

${ }^{27}$ KKI 32, 473. 


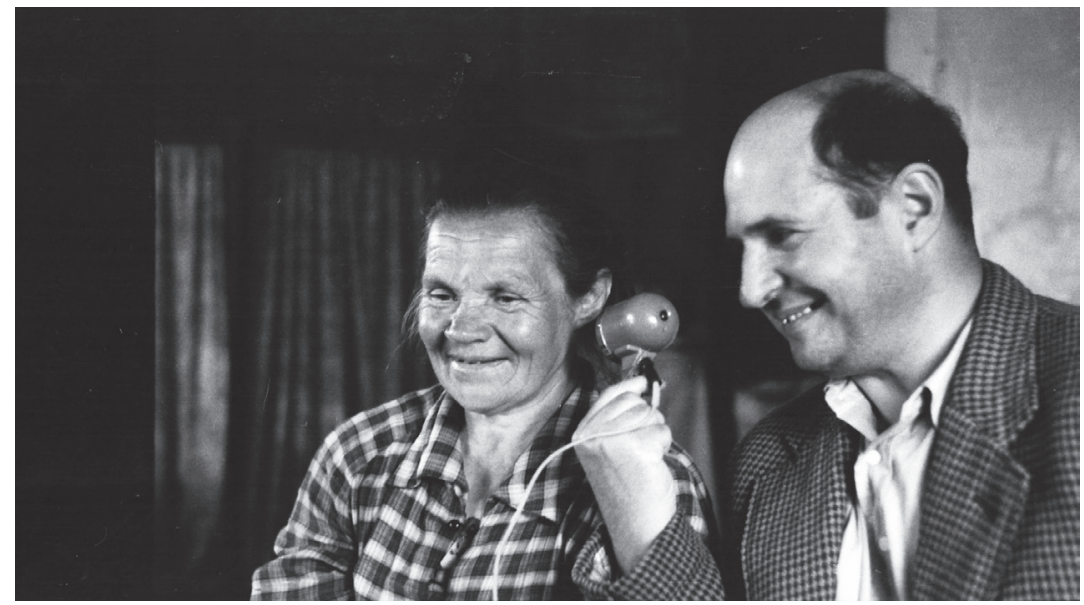

Maria Popljovkina ja Georg (Jüri) Šumakov Kuningakülas. Foto: Richard Viidalepp, 1960 (KKI, Foto 834).

Ühelt poolt tundis ta ekspeditsioonijuhina kohustust juhendada ja kontrollida teisi kogujaid, teisalt tema isiklikud uurijahuvid ja kogumismeetodid süvendasid tema eraldumist lärmakast ja pinnapealsest suhtlemisest. Schmidti puhul oli ta sunnitud laskma tal iseseisvalt koguda, kuigi lõpptulemuseks oli (oodatult) süvenematus ja liiga hõre pärimuse jäädvustamine.

Siiski, aastate jooksul kohanes ka Viidalepp ise: käis vene külades ja küsitles vene jutustajaid ega kõhelnud venekeelseid üleskirjutusi tegemast. Nii näiteks August Annistiga koos tehtud automatkal Peipsi ümbruses ja Alutagusel "Kalevipoja jälgedel" proovis ta kindlaks teha vene vägilaste ja eesti hiiumuistendite motiivide tuntust ja levikut mõlemakeelsete isikute seas.

Mustvee linna serval pü̈̈dsin juttu alustada paari venelasega. Neist noorem teadis midagi ka eestlaste ainestikust. (KKI 32, 319-Richard Viidalepp (1959)) 


\section{Vahelepõige Peipsitagusesse}

Võib öelda, et toonaste suurekspeditsioonide ideaalile vastas kõige rohkem 1958. aasta juulis toimunud ekspeditsioon Peipsitagustele aladele (Leningradi ja Pihkva oblastisse), mille korraldasid Eesti NSV Teaduste Akadeemia Ajaloo Instituut ja NSVL Teaduste Akadeemia Etnograafia Instituut. Eesti teadlastest osalesid lisaks Viidalepale etnoloogid Aliise Moora ja Ants Viires, keeleteadlased Paul Ariste ja Arvo Laanest ning kunstnikud Evi Tihemets ja Herald Eelma. Viidalepa ekspeditsioonipäevikust ${ }^{28}$ ilmneb, et suurte lootustega alanud ekspeditsioonil tekkisid vastuolud uurijate huvides. Eesti teadlaste vähemus ei suutnud oma soove - Eesti asunduste külastamine - kuuldavaks teha ning olid sunnitud alluma enamuse eelistustele.

Lootsin, et hommikul läheme veel uuesti simititslaste juurde. Otsime üles mõne põlise eestlaste talu, vaatame ehitusi, esitame küsimusi. Kuid sellest ei tulnud midagi välja: venelasi see muidugi ei huvitanud, eestlased ei esitanud oma soove aga kuigi nõudlikult. Polnud päris selge, kuidas selle eksp. juhtimine tegelikult hakkab toimuma. (KKI 32, 13)

Kuna nelja nädala jooksul läbiti pikki vahemaid Kingissepast kuni Kraasna eestlasteni välja, muutus ekspeditsioon ekskursioonilaadseks läbikihutamiseks Peipsi tagustest küladest. Laialivalguvate eesmärkide koondamise asemel näidi lähtuvat juhuslikest huviäratajatest ja oludest, peale üksikute erandite ei peatutud kuskil pikemalt.

Ühes läbisõidetavas külas nägime jälle huvitavaid maju. Kuid ei lastud peatuda: kui halva teega jääd peatuma, siis pärast ei saagi enam edasi! (KKI 32, 19)

Õhtu eel siiski tuli väljasõit kõne alla, kuid miskipärast oli soovijaid vähe. Seetõttu sattusin minagi sellesse gruppi, kes pidi vaatama minema küla, mille nimeks on olnud Tšuhhonskie Zahhodõ. Sõitjaid oli kolm: mina ja kaks Moskva tüdrukut. Tundus imelik õhtu eel minna veel kodust kaugele, sest seal ei jää aegagi küsitlemiseks. Kuid meil pole kombeks oma ettevõtteid asjalikult läbi kaaluda. (KKI 32, 54)

28 "Ekspeditsioonilt Peipsitagusele alale juulis 1958” (KKI 32, 1/136). 


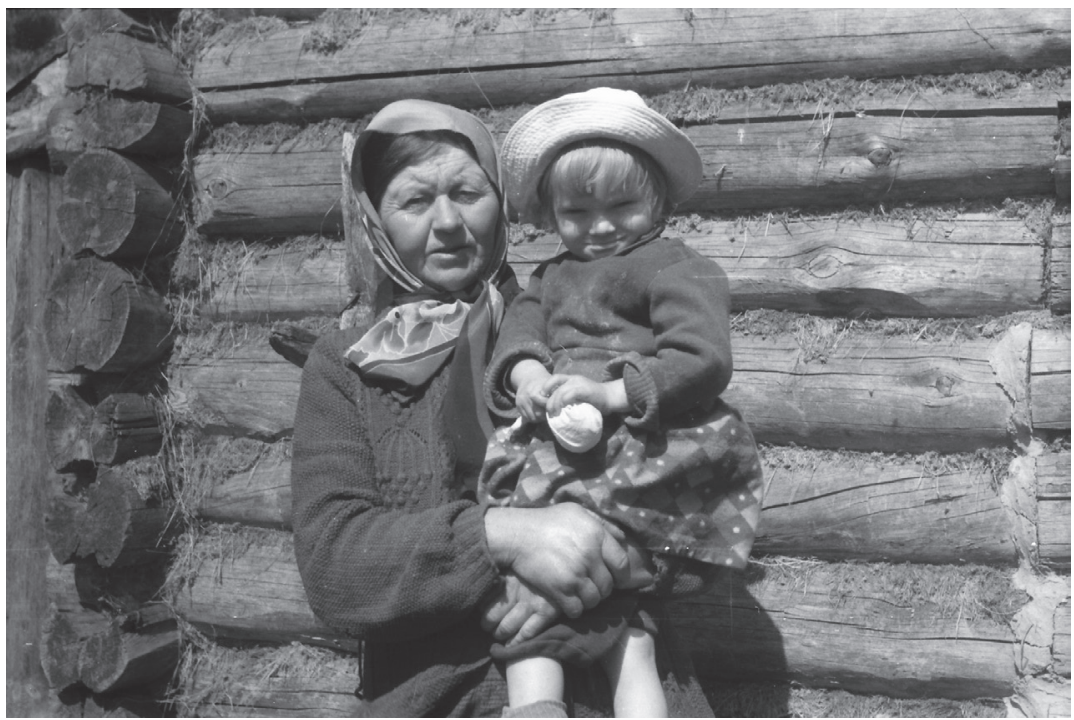

Jutustaja Anastasia Grizkina Tšudskije Zahodõ külast. Foto: Richard Viidalepp, 1958 (KKI, Foto 637).

Siiski tundub, et koordineerimismuredele vaatamata kohanes Viidalepp sellise töömeetodiga ning jätkas oma huvialadel küsitlemist, kirjeldades oma päevikus eestlaste järeltulijaid, nende keeleoskusi ja kombed. Küsitlemine toimus valdavalt vene keeles, kuna eestlaste kogukonnad olid kas hääbunud (Peipsitagused külad hävitati sõja ajal) või venestunud.

Hiiumuistendite motiive leidis Viidalepp küll vähe, kuid Oudovast ülespoole aina rohkem. Nii et ta võis rahulolevalt tõdeda: "Pole enam kahtlust, et siin - Peipsi tagusel alal - leidub mitmeid paralleele eesti vägilasmuistenditele" (KKI 32, 93). Sellelaadse edu tõttu sõitis Viidalepp tagasi põhjapoolsele Peipsitagusele (kuni Oudovani) 1960. aastal koos Jüri Šumakovi ja Heino Pedusaarega. ${ }^{29}$ Selle lühiekspeditsiooni käigus tõdes ta taas eestlaste venestumist.

${ }^{29}$ Vt päevik "Ekspeditsioon Narva jõe ümbrusse ja Pepsi taha 30. VII 6. VIII 1960” (KKI 32, 489/535). 


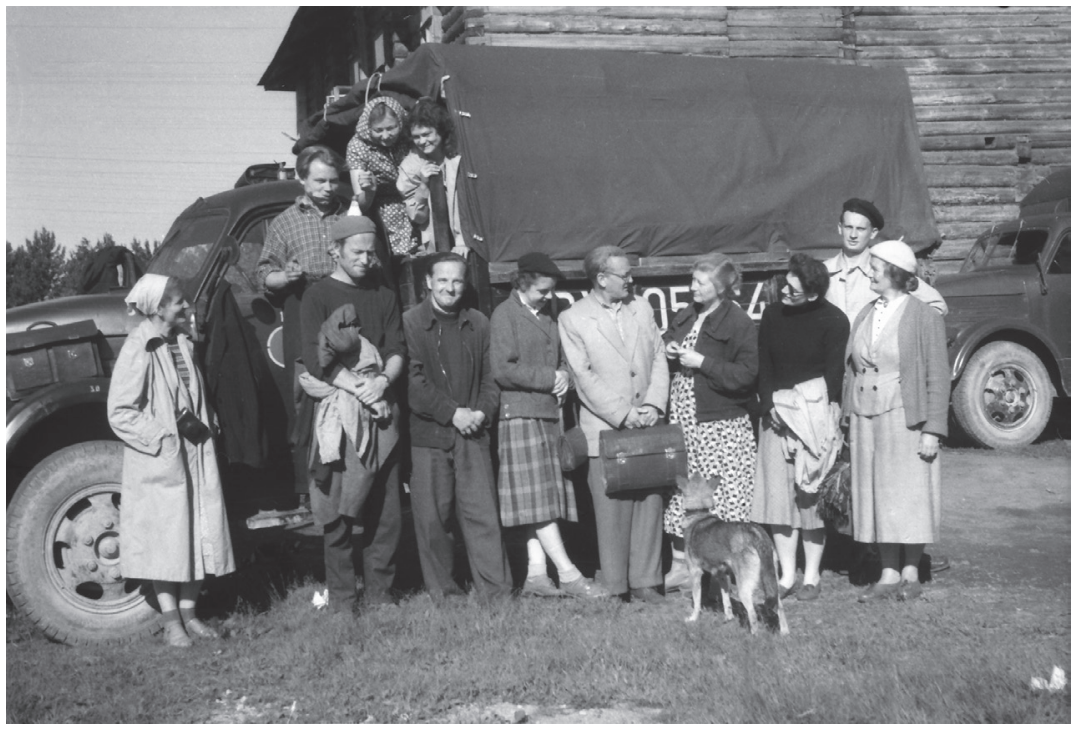

Peipsitagusest ekspeditsioonist osavõtjaid Oredežis. Üleval Evi Tihemets.

Esireas vasakult teine Herald Eelma, kolmas Ants Viires, viies Paul

Ariste. Paremalt esimene Aliise Moora, teine Arvo Laanest.

Foto: Richard Viidalepp, 1958 (KKI, Foto 666).

Ainuke eestlaste perekond selles Novaja külas. Koduseks keeleks vene keel. Vanemad lapsed oskavad ka eesti keelt. Peremees ise on käinud ainult vene koolis, sest eesti koole pole olnud. (KKI 32, 530)

Paraku, nii nagu Kodavere ja Setu-Räpina ekspeditsioonide materjal, nii jäi ka Alutaguse ja Peipsi-ümbruse venekeelne pärimus eraldi käsikirjadesse seisma. Sarnaselt "nõukogude folklooriga" ei kasutatud neid uurimuste allikatena, vaid üksnes aruannetes esitamiseks. 


\section{Kelle omad olid Kalevipojad?}

Kalevipoja temaatika prestiižsus ja perspektiivikus tekitab mitmeid intrigeerivaid küsimusi 1950. aastate eesti folkloristika erialase konkurentsi kohta. Mida toona koguti ja mida deklareeriti kogutavat? Kellele - ehk toonases sõnastuses - kelle tööplaani kuulus Kalevipoeg? Kalevipoja pärimusega olid kõige deklaratiivsemalt seotud TRÜ kirjanduse ja rahvaluule kateeder eesotsas Eduard Laugastega, kes oli sõjajärgses folkloristikas silmapaistvalt kõrgelennulise karjääriga ning kahtlemata sõna- ja mõjuvõimas isik. Kuna Laugaste oli juhtival positsioonil nii eepose kui ka akadeemilise hiiumuistendite avaldamise juures, oli tal võimalus juba 1950. aastast saata tudengeid "kolhoosifolkloori" kampaaniaga paralleelselt koguma Kalevipoja pärimust. Välitööd toimusid peamiselt Virumaal, Rakvere, Tapa, Kose, Mustvee ja Jõgeva rajoonis; tudengid käisid ka Alutaguse piirkonnas 1954. ja 1955. aastal. ${ }^{30}$ Nende välitööde esmane eesmärk oli Kalevipoja nimega seotud paikade ja muististe otsimine, jäädvustamine ja inspekteerimine (Ariste \& Laugaste 1952; vt ka Hiiemäe 2003, 67), juttude folkloorsed eripärad (motiivid, varieerumine, esituse iseärasused) jäid tahaplaanile. ${ }^{31}$

Ka Viidalepa eriülesandeks jäi KKI RS Virumaa ekspeditsioonisarja lõpuni eesti-vene suhete ja hiiupärimuse jäädvustamine (vt nt KKI 22, 576/9). Selle põhjuseks oli kahtlemata tema varasem huvi kohapärimuse ja hiiumuistendite vastu - oli ta ju 1930. aastate lõpus juhtinud kohapärimuse kogumisaktsiooni ERAs ning kirjutanud vastavasisulisi artikleid (nt Viidalepp 1939).

Kuid tudengite ja KKI folkloristide välitööde paralleelsus ning kattumine ajas ja ruumis, samas aga koostöö puudumine jätab mulje huvide konfliktist ja temaatilisest dubleerimisest. On täiesti ilmne ja arusaadav, et erinevate folkloristlike institutsioonide vahel jagati ja piiritleti uuritavad teemad ning kogumispiirkonnad. ${ }^{32} \mathrm{KKI}$,

${ }^{30}$ Vt nt Virve Murumaa ja Ülo Tedre kogumispäevikut 1950; 1951 Anita Riis; 1952 Ingrid Sarv ja Ellen Veskisaar, Anita Riis; 1954 Anita Rõõm, Maie Võerahansu; 1955 Anita Rõõm. Päevikute arhiiviviited vt lisa 2.

31 Ülo Tedre ongi kritiseerinud Laugaste akadeemilist muistendiköidet seetõttu, et väljaande tüpoloogia aluseks on kinnismuistis, mitte muistendisüžee (Tedre 2008, 136).

${ }^{32}$ Tööülesannete jagamiseks olid isegi vastavad institutsioonid, folkloristide teemasid jaotas Vabariikliku Koordineerimisnõukogu ajaloo ja filoloogia teaduste sektsioon, vt F 24, n 1, s 269. 


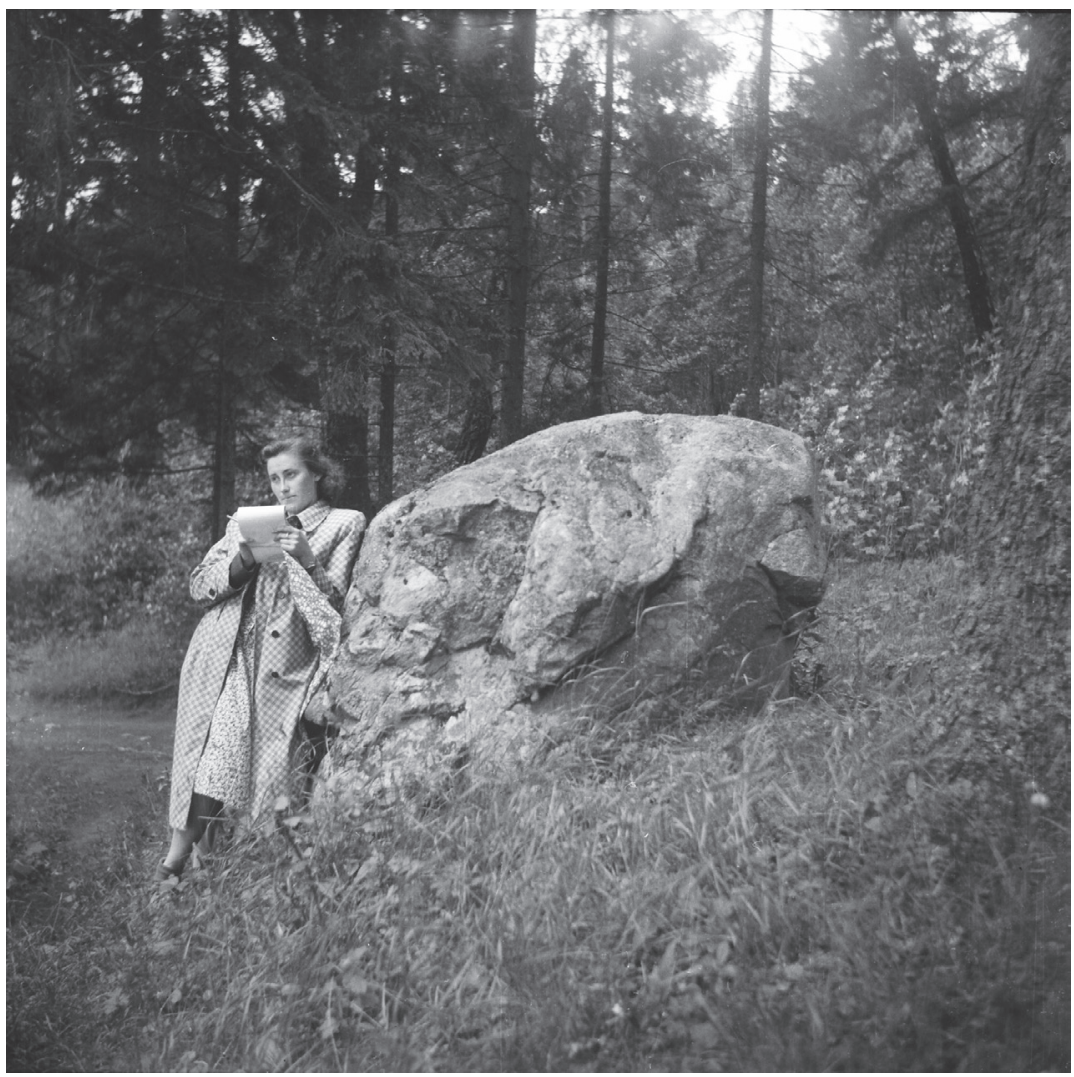

Rahvaluulekoguja Anita Riis Porkuni järve kaldal Porkunit kirjeldamas. Kaie-allika ligidal asuvat suurt kivi on oletatud Kalevipoja kiviks - teateid sellest ei leidnud. Foto: Ülo Tedre, 1951 (KKI, Foto 1045).

TRÜ ning RKM folkloristide 1955. a aprillis toimunud koordineerimisnõupidamise protokollist (F 24, n 1, s 269) saab lugeda asutuste rahvaluule kogumise plaanidest. Seal on märgitud nii TRÜ tudengite Kalevipoja jm hiiupärimuse kogumine kui RKM folkloristide eesti-vene(-vadja) suhete alane kogumine Peipsi rannikul Kodaveres. Alutaguse piirkond oli samuti jutuks, kuid RKM folkloristide tulevikuplaanidena. Viidalepp ei rääkinud sel koosolekul KKI ekspeditsiooniplaanidest, väljendades vaid pahameelt, et ühine 


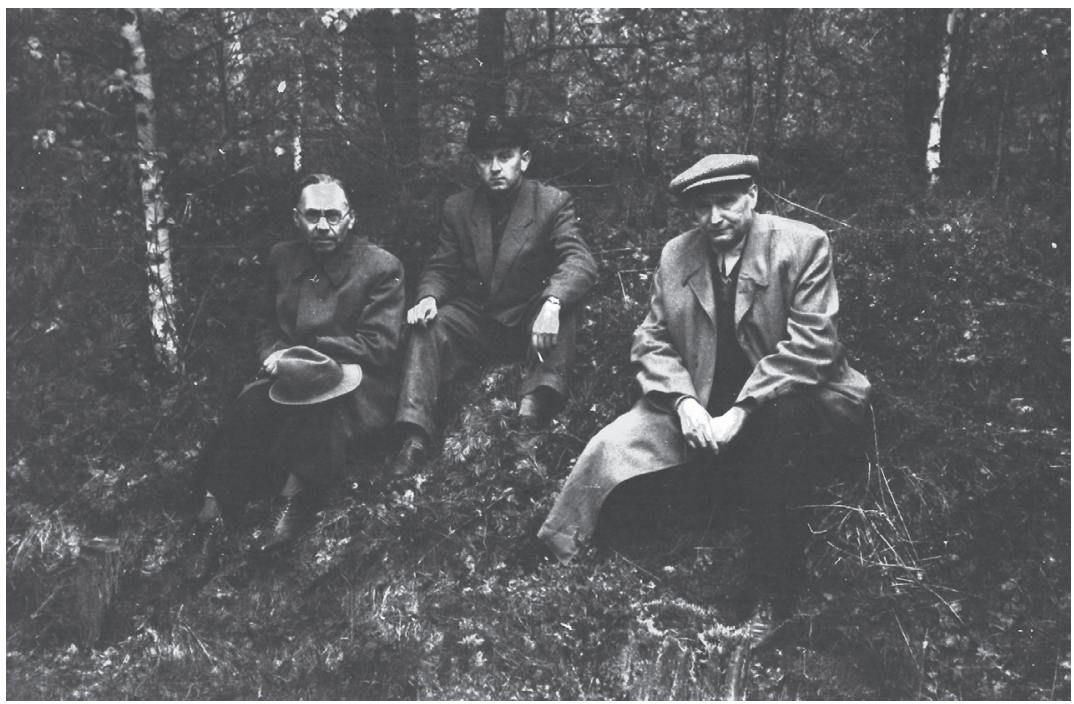

Peipsi lähistel Kalevipoja haual koos August Annistiga. Foto: Richard Viidalepp, 1959 (KKI, Foto 759).

ekspeditsioon Alutagusele RKM ROga ära jääb. Samuti ei rääkinud ta Kalevipoja juttude kogumisest Alutagusel. Selle protokolli põhjal jääb mulje, et Viidalepp ei avaldanud oma huve Kalevipoja juttude osas enne ekspeditsiooni(sarja) toimumist.

Võimalik, et KKI RS välitööde frontaalsus, muude žanride kaetus ja kohatine muusikalisele folkloorile keskendatus, eriti aga deklaratiivne fokuseeritus eesti-vene suhetele kompenseeriski huvide konflikti ja hägustas võimaliku skandaali teravikku.

Tagantjärele peab aga nentima, et Viidalepa huvi Peipsi-ümbruse Kalevipoja muistendite vastu jäi väärilise väljundita. Viidalepp ei olnud akadeemilise hiiu- ja vägilasmuistendite seeria toimkonnas. Tema kogutud jutte, v.a esimesel 1955. aasta ekspeditsioonil kogutuid, ei avaldatud ei seeria esimeses, Kalevipoja köites ega kolmanda köite lisades. Võib olla mitmeid põhjuseid, miks vaatamata ammendavuse taotlusele jäi palju KKI folkloristide kogutud jutte avaldamata. Nagu Mall Hiiemäe märgib (2003, 67-69), võis oma osa olla tõsiasjal, et Alutaguse Kalevipoja-muistendid polnud sugugi nii 
venesõbralikud kui valitsev ideoloogia ette nägi. Viidalepp ise kirjutas Kalevipoja muistendite motiividel mõned artiklid, ${ }^{33}$ kuid monograafiat ei sündinud. Samas, arvestades toonaseid kirjastusolusid ja üldist produktiivsust, võib küllap sedagi õnnestumiseks pidada.

Kõige suurem kaotus on aga see, et neil Viidalepa juhitud Alutaguse ekspeditsioonidel kogutud materjal on jäänud kuidagi üldisest kasutusest kõrvale. Nii nagu ei jõudnud enamik Alutaguse ekspeditsioonidelt kogutud regilaule ja -viise Vana Kandle JõhviIisaku köitesse (vt Saarlo 2017a, 133-134), ei ole ka kohapärimus väärikat käsitlust leidnud hilisemates uurimustes (nt Kalda 2017). Arvata võib, et lisaks tehnilistele põhjustele - omaaegsed käsikirjade kättesaadavuse ja kopeerimisprobleemid ${ }^{34}$ - ning keerulistele inimeste-vahelistele suhetele mängis siinjuures rolli ka Viidalepa liigne introvertsus. Tema tagasihoidlikkus kogutud materjali tutvustamisel põhjustas KKI käsikirjakogude marginaliseerumise ja unustuse.

\section{Lõpetuseks}

Rääkides sõjajärgsetest stalinistlikest aastatest Eesti folkloristikas ja humanitaarias ei saa eirata poliitilist survet ja sundust, mis mõjutasid toonaseid teadlasi ja akadeemilisi valikuid. Teisalt ei saa aga kõrvale jätta inimeste kohanemisvõimet, oskust kohastuda ka kõige rängemates oludes. Kohustuslikust "ebateadusest" - nagu "kaasaegne nõukogude folkloor" võis Eesti Vabariigis hariduse saanud folkloristidele tunduda - osati üsna sujuvalt eemale libiseda.

Nii toimus ka rahvaste vaheliste suhete teemaga - eesti ja vene rahvaste sõpruse kohustusliku käsitlemise käigus uuriti ja koguti ikka, mis tundus huvitav ja ühendav. Etnogenees ja Kalevipoeg päästsid Eesti rahvusteadused, nende kattevarjus pöördus Eesti folkloristika oma tavapärastesse rööbastesse tagasi.

Siiski tähendas see ka folkloristika omamoelist konserveerumist. Rahvastevaheliste suhete temaatikasse ei süvenetud kuigivõrd,

${ }^{33}$ Eesti rahvaluule bibliograafiast (1919-1992) leiab kolm artiklit (Viidalepp 1958; 1961; 1968), kuid neid ilmus ka ajalehtedes, mille sisu bibliograafias avatud ei ole (nt Viidalepp 1951; 1957).

${ }^{34}$ KKI käsikirjakogu jõudis Tartusse rahvaluulearhiivi 2000. aastal. Käsikirjad on varustatud registritega, kuid nende sisu ei kajastu arhiivi temaatilistes kartoteekides. 
kogutud materjale esitati vaid "plaani täitmise" ja "ümberkasvamise" demonstreerimiseks. Venelastelt - ja ka poluvernikutelt - kogutud materjalid jäid seisma, neid ei uuritud edasi. Vene pärimuse kogumine hangus, kuni vene keele ja kirjanduse kateeder selle töö üle võttis.

Hiiu ja vägilasmuistendite kogumine ja uurimine püsis edukalt päevakorral, kohapärimuse küsimine lisandus vaikimisi välitööde kaanonisse ja elab praegu pisut muutunud kujul haripunktis. Ka suurte ekspeditsioonide korraldamine muutus enesest mõistetavaks, iga-aastased suured frontaalsed ekspeditsioonid püsisid nii kirjandusmuuseumi folkloristide kui ka Tartu ülikooli tudengite töömeetodina 1990. aastate lõpuni. Ja ometi jäi ka nende kõrval ja raames alati ruumi üksikutele rändajatele.

Artikli valmimist toetasid Haridus-ja Teadusministeerium (IUT 22-4 "Folkloor kultuurilise kommunikatsiooni protsessis: ideoloogiad ja kogukonnad") ning Euroopa Liit Euroopa Regionaalarengu Fondi kaudu (Eesti-uuringute Tippkeskus).

\section{LISA 1. Richard Viidalepa juhitud ekspeditsioonid Virumaal ja Peipsi ümbruses}

1. Iisaku 12.-24. juulini 1955 - Richard Viidalepp, Ülo Tedre, Loreida Raudsep, Helgi Kihno.

2. Tudulinna (Iisaku) 10.-23. juulini 1956 - Viidalepp, Tedre, Kihno, Raudsep, Vivian Jüris.

3. Kuremäe (Jõhvi) 28. juunist 10. juulini 1957 - Viidalepp, Raudsep, Kihno, Ester Mägi, Jüri Šumakov.

4. Illuka (Jõhvi) 17.-29. juunini 1958 - Viidalepp, Kihno ja Veera Schmidt.

5. Peipsi-tagused alad 6. juulist 3. augustini1958 - ENSV TA Ajaloo Instituudi ja NSVL TA etnograafia Instituudi ühisekspeditsioon.

6. Kalevipoja jälgedel (Tartu-Maarja; Kodavere; Torma; Iisaku; Peipsi ümbrus) 26.-30. maini 1959 - Viidalepp, August Annist, Jaan Viidalepp.

7. Illuka 29. juunist 3. juulini 1960 - Viidalepp, Alvine Schmuul, Aare Adler, Sumakov.

8. Narva jõe ümbrus ja Peipsi-tagune 30. juulist 6. augustini 1960 Viidalepp, Heino Pedusaar, Šumakov. 


\section{LISA 2. Virumaa kogumispäevikud aastaist 1947-1960}

Päevikud on kättesaadavad digiteeringute ja/või tekstistustena Eesti Kirjandusmuuseumi failirepositooriumis Kivike (kivike.kirmus.ee)

KKI 2, 9/19 < Haljala - Ellen Tarvel (1947).

RKM II 32, 9/13 < Jõhvi - Hilda Nõu (1949).

KKI 12, 265/99 < Simuna - Virve Murumaa; Ülo Tedre (1950).

EKRKI2,349/56 < Väike-Maarja; Rakvere; Kadrina-Anita Riis(1951).

KKI 18, 317/47 < Väike-Maarja; Rakvere; Kadrina - Ülo Tedre (1951).

RKM II 32, 181/204 < Jõhvi - Hilda Nõu (1951).

EKRK I 4, 123/41 < Rakvere; Viru-Jaagupi; Haljala; Kadrina - Anita Riis (1952).

EKRK I 4, 201/22 < Jõhvi; Iisaku; Torma - Anita Rõõm (1954).

EKRK I 4, 263/74 < Jõhvi; Iisaku; Torma - Maie Võerahansu (1954). EKRK I 11, 329/32 < Haljala; Viru-Nigula; Lüganuse - Eduard Laugaste (1955).

EKRK I 11, 57/78 < Vaivara; Jõhvi - Anita Rõõm (1955).

KKI 20, 23/63 < Iisaku - Loreida Raudsep (1955).

KKI 20, 233/56 < Iisaku - Helgi Kihno (1955).

KKI 20, 315/23 < Iisaku - Ülo Tedre (1955).

KKI 20, 355/437 < Iisaku - Richard Viidalepp (1955).

EKRK I 13, 303/49 < Haljala; Viru-Nigula - Maret Joamets (1956).

EKRK I 13, 77/100 < Haljala; Viru-Nigula - Helja Jõgise; Laine Loog (1956).

KKI 21, 121/39 < Iisaku - Helgi Kihno (1956).

KKI 21, 37/51 < Iisaku - Vivian Jüris (1956).

KKI 22, 17/58 < Iisaku - Loreida Raudsep (1956).

KKI 22, 561/89 < Iisaku - Richard Viidalepp (1956).

KKI 24, 183/90 < Jõhvi - Richard Viidalepp (1957).

KKI 25, 418/32 < Jõhvi - Ester Mägi (1957).

KKI 25, 5/17 < Jõhvi - Helgi Kihno (1957).

KKI 26, 434/40 < Jõhvi; Iisaku - Veera Pino (1957).

KKI 26, 7/29 < Jõhvi; Iisaku - Loreida Raudsep (1957).

EKRK I 13, 353/77 < Haljala - Viiu Ahas (1958).

EKRK I 13, 403/35 < Haljala - Hille Oona (1958).

KKI 24, 197/253 < Jõhvi - Richard Viidalepp (1958).

KKI 24, 421/36 < Jõhvi - Helgi Kihno (1958). 
EKRK I 26, 171/216 < Haljala - Ene-Reet Ennuse (1959).

KKI 32, 301/20 < Tartu-Maarja; Kodavere; Torma; Iisaku - Richard Viidalepp (1959).

EKRK I 31, 201/29 < Viru-Jaagupi - Ivi Hinn (1960).

EKRK I 31, 23/50 < Viru-Jaagupi - Ene-Reet Ennuse (1960).

EKRK I 32, 21/70 < Viru-Jaagupi - Peet Lepik; Paul-Eerik Rummo (1960).

KKI 32, 441/82 < Jõhvi - Richard Viidalepp (1960).

KKI 32, 489/535 < Narva linn; Vaivara; välismaa - Richard Viidalepp (1960).

\section{Käsikirjalised allikad}

EKRK - Tartu (Riikliku) Ülikooli eesti kirjanduse ja rahvaluule kateedri käsikirjaline rahvaluulekogu.

ERA - Eesti Rahvaluule Arhiivi käsikirjaline rahvaluulekogu.

F 24 - Eesti Kirjandusmuuseumi arhiiv.

KKI - Keele ja Kirjanduse Instituudi käsikirjaline rahvaluulekogu.

RKM - Eesti TA Fr. R. Kreutzwaldi nim. (Riikliku) Kirjandusmuuseumi rahvaluule osakonna käsikirjaline rahvaluulekogu.

TRÜ, VKK - Tartu Riikliku Ülikooli vene keele kateedri ja vene kirjanduse kateedri rahvaluulekogu.

\section{Elektroonilised allikad}

KIVIKE. Eesti Kirjandusmuuseumi virtuaalne kelder. kivike.kirmus.ee (05.05.2018).

\section{Kirjandus}

Aarelaid, Aili 1998. Ikka kultuurile mõeldes. Tallinn: Virgela.

Ahven, Eeva 2007. Pilk paberpeeglisse. Keele ja Kirjanduse Instituudi kroonika 1947-1993. Tallinn: Eesti Keele Sihtasutus.

Anderson, Walter 1926. Die Marspanik in Estland 1921. - Zeitschrift des Vereins für Volkskunde, Nr. 35/36, 229-252.

Andresen, Nigol 1949. "Kalevala" mälestuspäevade puhul. - Looming 3, 352-358.

Ariste, Paul 1930. Korjamismatkal poluvertsikute maal. - Eesti Kirjandus 8, 364-370. 
Ariste, Paul 1965. Vadja kohanimedes. - H. Moora, L. Jaanits (toim), Slaaviläänemeresoome suhete ajaloost. Eesti NSV Teaduste Akadeemia, Ajaloo Instituut, Keele ja kirjanduse Instituut, Fr. R. Kreutzwaldi nim. Kirjandusmuuseum. Tallinn: Eesti Raamat, 91-106.

Ariste, Paul \& Laugaste, Eduard 1952. Ekspeditsioonilisest tööst ajalookeeleteaduskonnas. - Tartu Riiklik Ülikool, 5.09.

EKA 1953 = Sõgel, Endel (toim) 1953. Eesti kirjanduse ajalugu: õpik keskkooli VIII klassile 1. Eesti NSV Teaduste Akadeemia Keele ja Kirjanduse Instituut. Tallinn: Eesti Riiklik Kirjastus.

ENSV 1955 = Naan, Gustav \& Vassar, Artur (toim). Eesti NSV ajalugu, I köide (kõige vanemast ajast XIX sajandi 50-ndate aastateni). Tallinn: Eesti Riiklik Kirjastus.

ENSV 1957 = Naan, Gustav (toim). Eesti NSV ajalugu (kõige vanemast ajast tänapäevani). Teine trükk. Tallinn: Eesti Riiklik Kirjastus.

ENSV TA 1965 = Alumäe, Nikolai (toim). Eesti NSV Teaduste Akadeemia aastail 1956-1964. Tallinn: Eesti NSV Teaduste Akadeemia.

Esmaspäev 1940 = Nõukogude Liidu rahvalaulikud. - Esmaspäev: Nädalalõpu leht 38, 21. september, lk 7 (http://dea.digar.ee/cgi-bin/ deaV?a=d\&d=esmaspaev19400921.2.26 - 17.03.2017).

Hennoste, Tiit 2010a. Hüpped modernismi poole II. 20. sajandi eesti kirjandusteadus Euroopa kirjandusteaduse taustal. 20. loeng: stalinistlik aeg I: institutsioonid, inimesed ja ideoloogia. - Vikerkaar 9, 91-102.

Hennoste, Tiit 2010b. Hüpped modernismi poole II. 20. sajandi eesti kirjandusteadus Euroopa kirjandusteaduse taustal. 18. loeng: stalinistlik aeg II: ümberhindamine. - Vikerkaar 10/11, 137-148.

Hiiemäe, Mall 2003. Vaateid vägilasmuistendile: Kalevipoeg ja Dobrõnja. - Kuutma, Kristin (toim). Paar sammukest XX. Eesti Kirjandusmuuseumi aastaraamat. Tartu: Eesti Kirjandusmuuseum, 61-75.

Hiiemäe, Mall 2013. Ida-Virumaa rahvakalendri erijoontest. - Rüütel, Ingrid (koost \& toim). Ida-Virumaa rahvakultuurist. Rakvere-Tartu: Viru Instituut, 109-125.

Kalda, Maie 2002. Vana kaader järel-eesti ajal võimalusi proovimas. - Keel ja Kirjandus 8, 572-578.

Kalda, Mare 2017. Virumaa kohajutud. Virumaa rahvakultuur I. - Mäetagused 66, 77-98 (doi: 10.7592/MT2017.66.kalda).

Kallasmaa, Marja \& Saar, Evat \& Päll, Peeter \& Joalaid, Marje \& Kiristaja, Arvis \& Ernits, Enn \& Faster, Mariko \& Puss, Fred \& Laansalu, Tiina \& Paales, Liina (koost) 2016. Eesti kohanimeraamat. Tallinn: Eesti Keele Sihtasutus.

Korb, Anu 2017. Virumaa rahvaluule kogumine ja kogujad. Virumaa rahvakultuur I. - Mäetagused 66, 9-32 (doi: 0.7592/MT2017.66.korb). 
Kreegipuu, Tiiu 2007. Eesti kultuurielu sovetiseerimine: Nõukogude kultuuripoliitika eesmärgid ja institutsionaalne raamistik aastatel 1944-1954. - Tannberg, Tõnu (koost). Eesti NSV aastatel 1940-1953: Sovetiseerimise mehhanismid ja tagajärjed Nõukogude Liidu ja IdaEuroopa arengute kontekstis. Eesti Ajalooarhiivi Toimetised 15 (22). Tartu: Eesti Ajalooarhiiv, 352-388.

Kreutzwald, Friedrich Reinhold 1953. Kalevipoeg. [järelsõna: E. Laugaste]. Tallinn: Eesti Riiklik Kirjastus.

Kulasalu, Kaisa 2017. From Estonian Folklore Archives to Folklore Department of the State Literary Museum: sovietization of folkloristics in late Stalinist Estonia. - Laime, Sandis \& Bula, Dace (toim). Mapping the History of Folklore Studies: Centers, Borderlands and Shared Spaces. Newcastle upon Tyne: Cambridge Scholars Publishing, 132-153.

Kümme aastat 1956 = Kümme aastat Eesti NSV Teaduste Akadeemiat (1946-1956). Eesti NSV Teaduste Akadeemia. Tallinn: Eesti Riiklik Kirjastus.

Laugaste, Eduard 1945. Mida tehakse ja kavatsetakse folkloori alal. - Rahva Hä̈̈l, nr 253, 26.10.

Laugaste, Eduard 1946. Eesti kirjanduse ajalugu 1. Eesti rahvaluule. Tartu: Teaduslik Kirjandus.

Laugaste, Eduard 1947. Kokkuvõtteid ja hinnanguid eesti rahvaluuleuurimise seniste saavutuste kohta. - Looming 8, 995-1003.

Laugaste, Eduard 1950. Ülesandeid Nõukogude Eesti rahvaluuleteaduses. - Edasi, nr 262.

Laugaste, Eduard 1959. Kalevi (Kalevipoja) nime esinemisest eesti rahvalauludes. - Keel ja Kirjandus 4-5, lk 202-208, 274-282.

Laugaste, Eduard \& Rõõm, Anita. 1958. Kalevipoja jälgedel. Tallinn: Eesti Riiklik Kirjastus.

Laugaste, Eduard \& Normann, Erna 1959. Muistendid Kalevipojast. Eesti muistendid. Hiiu- ja vägilasmuistendid I. Monumenta Estoniae Antiquae II. Tallinn: Eesti Riiklik Kirjastus.

Laugaste, Eduard \& Liiv, Ellen \& Normann, Erna 1963. Muistendid Suurest Tõllust ja teistest. Eesti muistendid. Hiiu- ja vägilasmuistendid II. Monumenta Estoniae Antiquae II. Tallinn: Eesti Riiklik Kirjastus.

Laugaste, Eduard \& Liiv, Ellen 1970. Muistendid Vanapaganast. Eesti muistendid. Hiiu- ja vägilasmuistendid III. Monumenta Estoniae Antiquae II. Tallinn: Eesti Raamat.

Ligi, Priit 2013. Etnilistest oludest Alutagusel muinas- ja keskajal. - Rüütel, Ingrid (toim). Ida-Virumaa rahvakultuurist. Rakvere-Tartu: Viru Instituut, 13-18. 
Liiv, Ellen 1961. Koguge muistendeid Vanapaganast! - Tampere, Herbert \& Normann, Erna (toim). Rahvapärimuste koguja 1. Kirjandusmuuseumi kogumistöö juhend nr. 1. Tartu: Eesti NSV TA Fr. R. Kreutzwaldi nim. Kirjandusmuuseum, 119-25.

Lippus, Urve 2008. Eesti muusika kaotused Nõukogude okupatsiooni läbi. - Ennuste Ülo \& Tarvel, Enn \& Varju, Peep (toim). Kannatuste aastad 1940-1991. Tallinn: Sihtasutus Valge Raamat, 175-214.

Lätt, Selma \& Tampere, Herbert 1961. ENSV TA Fr. R. Kreutzwaldi nim. Kirjandusmuuseumi rahvaluule-alased ekspeditsioonid 1960. a. suvel. - Tampere, Herbert \& Normann, Erna (toim). Rahvapärimuste koguja 1. Kirjandusmuuseumi kogumistöö juhend nr. 1. Tartu: Eesti NSV TA Fr. R. Kreutzwaldi nim. Kirjandusmuuseum, 79-81.

Oinas, Felix J. 1985. The problem of the Notion of Soviet Folklore. - Essays on Russian Folklore and Mythology. Columbus, Ohio: Slavica Publishers Inc., 160-179.

Olesk, Sirje 2003. "Laine põhi". Kirjandusest ja selle kontekstist Eestis aastatel 1950-1953. - Krikmann, Arvo \& Olesk, Sirje (toim). Võim ja kultuur. Tartu: Eesti Kirjandusmuuseum, 465-479.

Oras, Janika 2008. Viie 20. sajandi naise regilaulumaailm. Eesti Rahvaluule Arhiivi toimetused 27. Tartu: Eesti Kirjandusmuuseumi Teaduskirjastus.

Oras, Janika 2009. Lõik eesti folkloorikogumise loost: Nõukogude aja helisalvestused. - Akadeemia 4, 703-724.

Moora, Harri (toim) 1956. Eesti rahva etnilisest ajaloost. Eesti NSV Teaduste Akadeemia Ajaloo Instituut. Tallinn: Eesti Riiklik Kirjastus.

Moora, Aliise 1964. Peipsimaa etnilisest ajaloost. Ajaloolis-etnograafiline uurimus Eesti-Vene suhetest. Eesti NSV Teaduste Akadeemia, Ajaloo Instituut. Tallinn: Eesti Riiklik Kirjastus.

Pall, Valdek 1977. Põhja-Tartumaa kohanimed 2. Eesti NSV Teaduste Akadeemia, Keele ja Kirjanduse Instituut. Tallinn: Valgus.

Saarlo, Liina 2017a. Regilaul in the political whirlpool. On Collecting Regilaul in Northeast Estonia in the Second Half of the 1950s. - Folklore: Electronic Journal of Folklore 67, 115-142 (doi: 10.7592/ FEJF2017.67.saarlo).

Saarlo, Liina 2017b. Regilaul tuulte pöörises. Eesti folkloristid poliitiliste muutuste ajajärgul 20. sajandi keskel. - Methis. Studia humaniora Estonica 20, 27-54 (doi: 10.7592/methis.v16i20.13888).

Salve, Kristi 2002. Muude rahvaste folkloor Eesti Rahvaluule Arhiivis. - Hiiemäe, Mall (koost). Kogumisest uurimiseni. Artikleid Eesti Rahvaluule Arhiivi 75. aastapäevaks. ERA Toimetused 20. Tartu, 29-52.

Salve, Kristi 2013. "Lorijal lõuvad, kuuljal kõrvad." Ida-Virumaa rahvajuttudest. - Rüütel, Ingrid (koost \& toim). Ida-Virumaa rahvakultuurist. Rakvere-Tartu: Viru Instituut, 127-155. 
Tampere, Herbert 1949. Vene mõjusid eesti vanemais rahvaviisides. - Sirp ja Vasar, nr 3 (264).

Tampere, Herbert 1962. ENSV TA Fr. R. Kreutzwaldi nim. Kirjandusmuuseumi rahvaluule-alased ekspeditsioonid 1961. aastal. - Tampere, Herbert \& Rüütel, Ingrid (toim). Rahvapärimuste koguja 3. Kirjandusmuuseumi kogumistöö juhend nr. 3. Tartu: Eesti NSV TA Fr. R. Kreutzwaldi nim. Kirjandusmuuseum, 58-60.

Tedre, Ülo 1997. Keele ja Kirjanduse rahvaluulesektor 1947-1990. -Viikberg, Jüri (toim). Eesti filoloogia poolsajand Teaduste Akadeemias. Tallinn: Eesti Keele Instituut.

Tedre, Ülo 1999. Rahvalaulude kogumisest Jõhvis ja Iisakus. - Kokamägi, Hilja \& Tedre, Ülo \& Tuvi, Edna (koost). Vana Kannel VIII: Jõhvi ja Iisaku regilaulud. Estonum Carmina Popularia VIII. Monumenta Estoniae Antiquae I. Tartu: Eesti Keele Instituut, folkloristika osakond \& Eesti Kirjandusmuuseum, Eesti Rahvaluule Arhiiv, 84-100.

Tedre, Ülo 2008. Kalevipoeg ja tema uurimislugu. - Karjatse, Dana \& Adang, Richard (toim). Ühest sajandist teise. Kristjan ja Paul Raud. Eesti Kunstimuuseumi toimetised. Tallinn: Eesti Kunstimuuseum, 131-138.

Uuet, Liivi 2010. Esimesed Eesti töölisdelegatsioonid ja Stalini tervitused. - Tuna 1, 101-103.

Viidalepp, Richard 1937. Von einem grossen estnischen Erzähler und seinem Repertoir. - Acta Ethnologica 2 (3), 158-173.

Viidalepp, Richard 1939. Aruanne kohamuistendite kogumise võistluse tulemustest ja auhindadest. - Rahvapärimuste selgitaja 6. Tartu, 195-199.

Viidalepp, Richard 1951. Kalevipoeg - eesti ja vene rahva iidse sõpruse kehastaja. - Nõukogude Ôpetaja, nr 35 (386).

Viidalepp, Richard 1957. Mõnede Kalevipoja-muistendite seosest Venemaaga ja vene vägilasmuistenditega. - Edasi, 10.09, nr 179.

Viidalepp, Richard 1958. Kalevipoja pruut. -Keel ja Kirjandus 8, 474-475.

Viidalepp, Richard 1961. "Kalevipoja" ja Kalevipoja-muistendite uurimisest. - Keele, kirjanduse ja rahvaluule küsimusi. Keele ja Kirjanduse Instituudi uurimused 6. Tallinn: Eesti Riiklik Kirjastus, 110-140.

Viidalepp, Richard 1968. Ilja Muromets ja Dobrõnja Kuremäe ümbruses. - Keel ja Kirjandus 9, 551-557.

Viidalepp, Richard 1981. Õpinguist ja tööst. - Kaal, H (koost) \& Ahven, Heino (toim). Sõnavara probleeme. Emakeele Seltsi aastaraamat 25 (1979). Tallinn: Eesti Raamat, 107-111.

Viidalepp, Richard 1986. Meie esimene ekspeditsioon. - Ahven, Heino (toim). Keelest ja rahvaluulest. Emakeele Seltsi Aastaraamat 30 (1984). Tallinn: Eesti Raamat, 163-172. 


\section{Summary}

\section{Kalevipoeg and Dobrynya. Collecting folklore in Alutaguse in the 1950s}

Keywords: epic legends, fieldwork, history of folkloristics, poluvertsiks poluverniks (Lutherian Russians of Iisaku parish), relations between Estonia and Russia

Political pressure dominated the humanities in Estonia after World War II, impacting the life of scholars as well as their academic choices. Sovietisation meant that the form and substance of humanities in Estonia was altered to bring it into compliance with the Soviet system.

Conferences held in Moscow provided practical work instructions that were carefully distributed locally. But directives coming from "above" were constantly changing and former research subjects and methods could easily make scholars the targets of political repressions. Academics adapted to the new situation during the Stalinist years.

Relations between nations (with a conscious emphasis on the positive aspects), especially between Russians and Estonians, was a research subject that was continuously prioritised in post-war humanities. This topic was especially relative in border areas like those around Lake Peipus, in Ida-Viru County and in Southeastern Estonia. Folklorists organised large joint expeditions to these areas over a number of years.

The life and work of Friedrich Reinhold Kreutzwald (1803-1882) and the national epic Kalevipoeg was once again revived as a relative research subject since the latter conveniently fell in line with the topic of EstonianRussian relations courtesy of motifs in folk tales about heroes and giants.

This article presents an overview of how the topic of Estonian-Russian relations has been treated in Estonian folkloristics with emphasis on fieldwork performed by the Institute of Language and Literature in Ida-Viru County during the second half of the 1950s. The circumstances of fieldwork are addressed in the changing conditions of research policy and the age of renewal of collection methods.

With regard to the results of fieldwork and the treatment of collected materials, we must admit that folklorists then did not delve overly deep into the topic or relations between nations. The materials collected from Russians were submitted only to demonstrate "meeting the plan" and "reeducation" and not researched any further. However, the collection and research of folk tales about heroes and giants remained topical, and place lore was included in the default standard of folkloristic fieldwork. Even the organisation of large-scale fieldwork and all-encompassing expeditions became elementary and lasted until the end of the 1990s. 


\section{PILDI SISSE MINEK. Artikleid välitööde alalt}

\section{Koostanud ja toimetanud EDA KALMRE}

http://www.folklore.ee/rl/pubte/ee/cf/pildisisse

ISBN 978-9949-586-93-6

DOI $10.7592 / \mathrm{TF} 11$

Tartu 2019

Trükis ilmunud:

Pildi sisse minek. Artikleid välitööde alalt.

Tänapäeva folkloorist 11. Tartu 2019

Sarja peatoimetaja: Eda Kalmre

Kogumiku koostaja ja toimetaja: Eda Kalmre

Keeletoimetaja: Asta Niinemets

Kaanekujundus: Artur Kuus

Küljendus: Diana Kahre

Veebiväljaanne: Diana Kahre

Trükitud Eesti Kultuurkapitali toetusel. Väljaande valmimine on seotud Euroopa Liidu Euroopa Regionaalarengu Fondi (Eesti-uuringute Tippkeskus) ja Eesti Haridus- ja Teadusministeeriumi uurimisprojektiga IUT 22-5. Väljaande valmimist on toetanud Akadeemiline Rahvaluule Selts.

E-raamatu valmimist toetas: EKKM14-344 Eesti keele, kultuuri ja folkloori kasutusalade laiendamine ja tutvustamine elektroonilistel infokandjatel.

(C) Eesti Kirjandusmuuseum 2019

(C) Eda Kalmre ja autorid

(C) Artur Kuus 